\title{
Chapter V.1
}

\section{Islet Transplantation in Type 1 Diabetes: Ongoing Challenges, Refined Procedures, and Long-Term Outcome}

\author{
A.M. James Shapiro \\ Clinical Islet Transplant Program, University of Alberta, 2000 College Plaza, 8215 112th Street, Edmonton AB Canada T6G 2C8, e-mail \\ amjs@islet.ca
}

Manuscript submitted December 16, 2012; accepted Jan uar y 21, 2013

\section{Abstract}

Remarkable progress has been made in islet transplantation over a span of 40 years. Once just an experimental curiosity in mice, this therapy has moved forward, and can now provide robust therapy for highly selected patients with type 1 diabetes (T1D), refractory to stabilization by other means. This progress could not have occurred without extensive dynamic international collaboration. Currently, 1,085 patients have undergone islet transplantation at 40 international sites since the Edmonton Protocol was reported in 2000 (752 allografts, 333 autografts), according to the Collaborative Islet Transplant Registry. The long-term results of islet transplantation in selected centers now match registry data of pancreas-alone transplantation, with 6 sites reporting five-year insulin independence rates $\geq 50 \%$ Islet transplantation has been criticized for the use of multiple donor pancreas organs, but progress has also occurred in single-donor success, with 10 sites reporting increased single-donor en-

\section{Overview perspective}

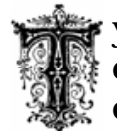

ype 1 diabetes (T1D) is an autoimmune disease characterized by the destruction of betacells within the pancreas, resulting in absolute deficiency of insulin. Hyperglycemia, ketoacidosis, and dehydration are the immediate consequences if left untreated. Subcutaneous bolus injection of insulin has been the definitive, life sustaining therapy since 1922, following its discovery by Nobel Laureates Banting, McCleod, and co-workers Best and Collip. Standard or intensive insulin therapy remains the gold-standard therapy graftment. The next wave of innovative clinical trial interventions will address instant blood-mediated inflammatory reaction (IBM IR), apoptosis, and inflammation, and will translate into further marked improvements in single-donor success. Effective control of auto- and alloimmunity is the key to longterm islet function, and high-resolution cellular and antibody-based assays will add considerable precision to this process. Advances in immunosuppression, with new antibody-based targeting of costimulatory blockade and other $\mathrm{T}$ $B$ cellular signaling, will have further profound impact on the safety record of immunotherapy. Clinical trials will move forward shortly to test out new human stem cell derived islets, and in parallel trials will move forward, testing pig islets for compatibility in patients. Induction of immunological tolerance to self-islet antigens and to allografts is a difficult challenge, but potentially within our grasp.

Keywords: diabetes · islet - transplantation - immunosuppression · allograft

for the majority of patients with T1D. Tight glycemic control lessens the risk of secondary diabetic complications, but substantially increases risk of troublesome and occasional life-threatening hypoglycemia. For a minority of patients, a life troubled by frequent hypoglycemia, and fear of the 'dead-inbed' syndrome or of progressive complications, is not tolerable, and alternative strategies become increasingly attractive [3-6]. Whole pancreas transplantation remains a realistic option for some patients, especially in the setting of renal failure where a combined kidney-pancreas can be lifechanging, restoring euglycemia with considerable 
reserve. However, this approach requires major surgical intervention with attendant risk of complications and occasional mortality.

A far more elegant means to restore endogenous, physiologic insulin secretion was conceived and tested in 1893, almost 30 years before the discovery of insulin, when Williams and Harsant from Bristol, England, transplanted sheep pancreatic fragments subcutaneously under chloroform anesthesia in a desperate attempt to save a 15 year old boy dying of ketoacidosis [7]. The boy succumbed on the third day after the xenograft failed.

The concept of cellular replacement therapy for T1D lay dormant for 80 years until 1972, when Ballinger and Lacy cured chemical diabetes in rats by islet transplantation $[8,9]$. I ntensive, collaborative research over the next 40 years has moved islet transplantation forward as a viable option for highly selected T1D patients with 'brittle' control. Essential steps on this recent journey include the Ricordi Chamber for large-scale processing of the human pancreas [10], density-gradient islet purification on cell apheresis systems [11], and optimized processing and culture conditions in clinical good manufacturing practice (cGMP) facilities [12].

Lacy's team carried out the first successful clinical islet transplant in 1989. Insulin independence lasted for one month, but the cells were rejected due to inadequate immunosuppression [13]. More success was obtained with islet autotransplantation after surgical pancreatectomy for chronic pancreatitis. No immunosuppression was needed, and autoimmunity was not an issue, which explained the higher rates of insulin independence [14]. Tzakis et al. performed abdominal extirpation with combined abdominal liver and islet transplantation in 1990, and half the cohort attained insulin independence before dying from recurrence of abdominal malignancy $[15,16]$.

The concept of islet replacement clearly worked and was enticing, but the added challenge of autoimmune T1D seemed to create an insurmountable barrier. Indeed, 447 attempts to treat T1D with islet transplantation were made between 1974 and 2000, but the results were dismal, with less than $10 \%$ maintaining insulin independence and only $28 \%$ having detectable C-peptide by one year [17]. The introduction of the Edmonton Protocol in 2000 was therefore seen as a milestone success, as $100 \%$ of the first 7 patients treated achieved and maintained insulin independence at one year [18]. An essential component was the use of corticosteroid-free immunosuppression with anti-CD25 monoclonal antibody (mAb) induction and maintenance tacrolimus and sirolimus. Of

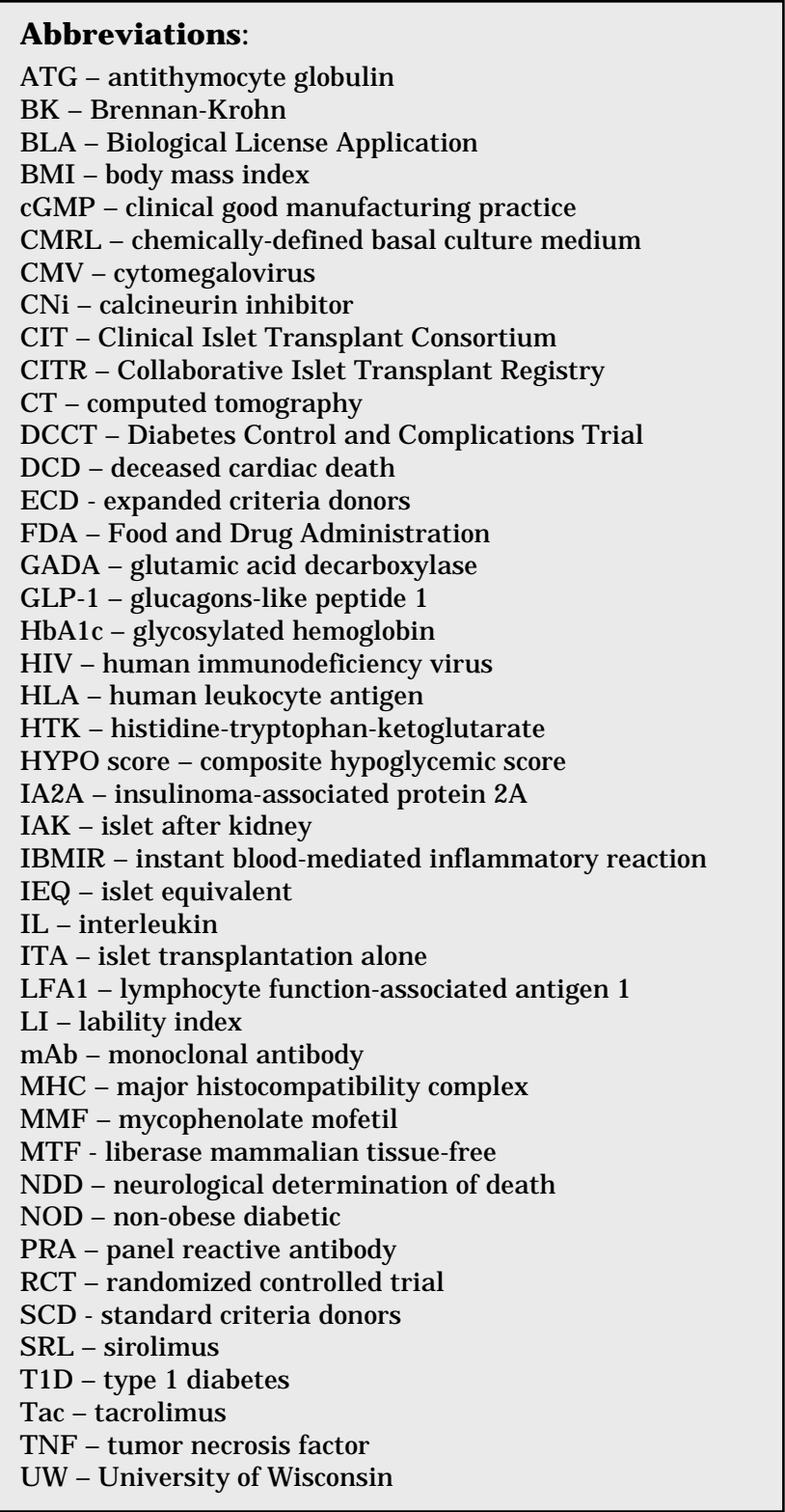

equal importance was the delivery of a sufficiently large islet transplant mass (>10,000 islet equivalents (IEQ)/kg recipient body weight) prepared from two or more donors.

Clinical islet transplantation has since transitioned over the past 13 years from rare, experimental curiosity to routine treatment, providing robust glycemic control for a small subset of 'brittle' TID patients refractory to stabilization by other means. Since 2000, 1,085 patients have undergone islet transplantation at 40 international sites (752 allografts, 333 autografts), according to the Collaborative Islet Transplant Registry (CITR) [19]. The most active clinical center (University of 


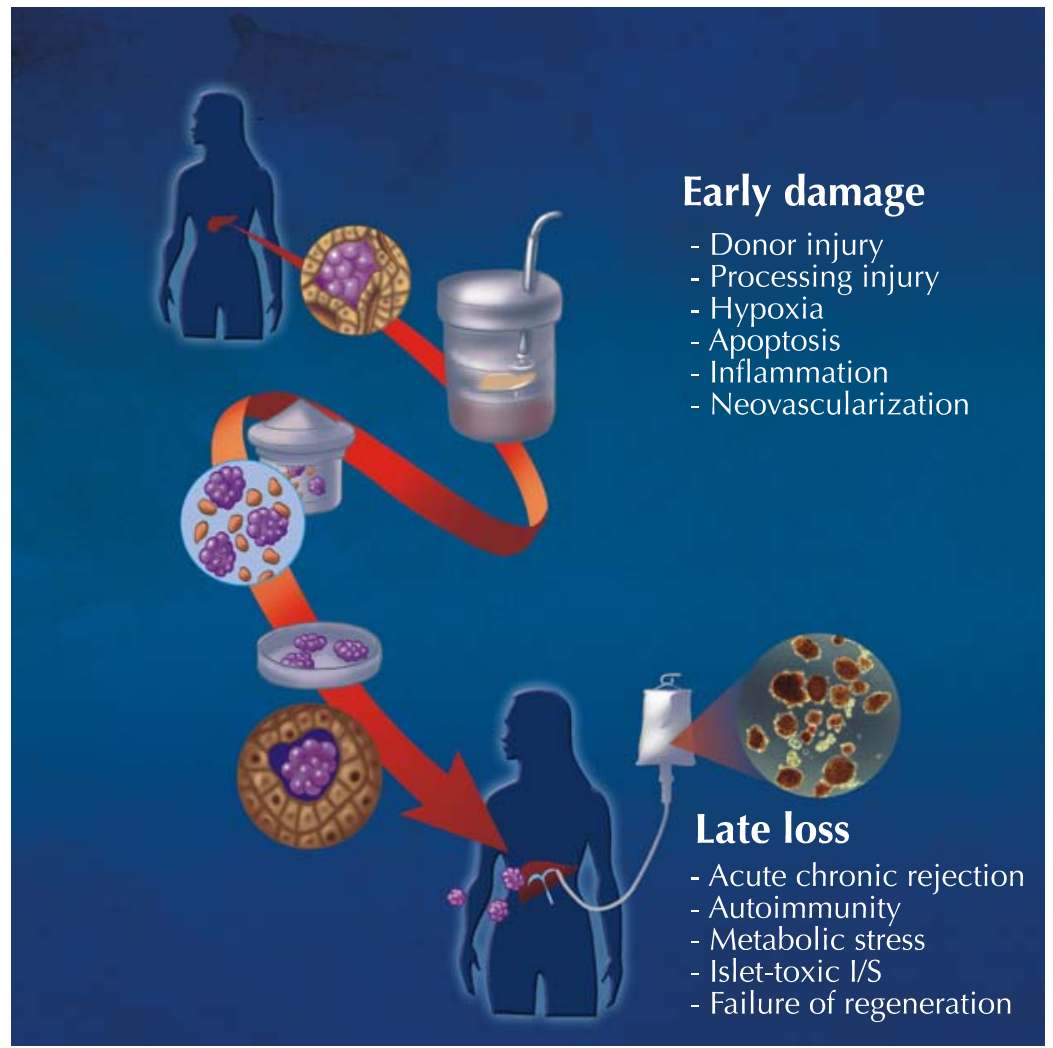

Figure 1. Illustration of the steps involved in pancreatic digestion, including islet isolation and intraportal transplantation within the liver. Inset photomicrograph shows human islets stained with dithizone red dye, indicative of a highly pure preparation. The lower inset labels indicate the challenges involved with early islet damage post-transplant, and the factors leading to late islet graft loss; both of which must be addressed to maintain excellent longterm graft function.

Alberta) performed a total of 61 islet transplantations in 2012 alone, and has done a cumulative total of 382 transplantations in 183 recipients to the present day. At least in expert hands, islet transplantation may be considered among the safest of all transplantation procedures compared with solid organs. In several countries, including Canada, Australia, the United Kingdom, France, Switzerland, Norway, Sweden, and other parts of Europe, islet transplantation is funded as 'non-research' standard clinical care. Major trials are underway in the US, funded by the National Institutes of Health through the Clinical I slet Transplant Consortium $(\mathrm{CIT})$, designed to generate sufficient data for a Food and Drug Administration's (FDA) Biological License Application (BLA). Two registration trials (CIT-06, islet-after-kidney, and CIT-07, isletalone) will deliver data in 2015 that will likely fa- cilitate insurance reimbursement through Medicare, Medicaid, and other third-party payers. Funding for islet processing and clinical care has been a major rate-limiting step in the US, and reimbursement will certainly lead to a more sustained and expanded clinical activity.

This review highlights the recent progress in islet isolation and clinical transplantation that now justifies further expansion of islet transplantation. An adequately powered, head-to-head randomized, controlled trial (RCT) of islet transplantation with intensive insulin and insulin pumps is much needed, but may be difficult to fund. In the longer term, a limited human islet supply and the need for intense immunosuppression are seen as the two drawbacks that prevent broader application of islet transplantation in T1D $[20,21]$. I mprovements in single-donor transplant engraftment, techniques to expand islet mass in vitro, and alternative cellular therapeutics, including human stem cell-derived islets or a xenogeneic pig source, will be required to bridge the gap in supply. To minimize the risk from immunosuppression, immunological tolerance is desirable, but will be challenging to establish in the presence of dual allo- and autoimmunity. Despite the perceived and known risks of current immunosuppression, risks are likely equivalent or perhaps lower than the risks of poorly controlled T1D and accelerated complications, but a matched RCT is needed to determine this with clarity. Transplanting early in the course of T1D could further improve the protective benefit, but justification for inclusion of children will require additional advances in immunosuppression and monitoring [22]. The riskbenefit equation would be improved considerably if we had effective, predictive immune biomarkers for autoimmunity and alloresponsiveness. Progress in peripheral blood T cell and antibody-based assays of auto-and alloreactivity may change this 
equation, permitting more precise titration of therapy to those with higher immunologic risk, while considerably lowering risk of infection or malignancy for those at less risk [23-25].

Successful islet transplantation begins with the selection and care of the multiorgan donor. Protection of the pancreas during transportation with minimization of cold ischemic injury is important for islet viability. The sequential steps involved in islet processing, purification, and culture are critical to the quality of the final islet product (Figure 1). Detailed clinical protocols are required for safe cellular transplantation, and for effective control of inflammation, auto- and alloimmunity, if the islet graft function is to be sustained longterm, while minimizing recipient risk. What follows is a step-by-step overview of the critical steps, and is based on a remarkable collaborative consensus between international investigators.

\section{Donor selection, pancreas pro- curement, islet isolation and culture}

While careful donor selection is imperative to avoid transmissible infection or malignancy, expensive processing of organs is unlikely appropriate to yield potent islets. Multivariate analyses suggest an optimal donor age $>20$, high donor BMI (provided $\mathrm{HbAlc}<6.0 \%$ ), normoglycemia, no hypotension or cardiac arrest, and minimal inotropic support as key to successful islet isolation [26-34]. Donor selection is especially critical for the success of single-donor islet engraftment; donor age $<50$ and $\mathrm{BMI}>27 \mathrm{~kg} / \mathrm{m}^{2}$ were important components of the Minnesota series [35, 36]. Recent refinement in isolation techniques by the San Francisco group, a collaborative member of $\mathrm{CIT}$, has resulted in marked improvement in islet yield from younger donors. Combined with improved single-donor success rates, these techniques may have an important impact on future allocations of pancreas organs for whole pancreas vs. islet transplantation $[33,37-40]$.

The majority of donors fall into the categories standard criteria donors (SCD) or expanded criteria donors $(E C D)$, where the heart is beating, but there is neurological determination of brain death (NDD). To address the donor shortage, increasing use of deceased cardiac death (DCD) donors are be ing used, where circulation has ceased and organs are subject to warm ischemic injury. DCD donors have been used successfully for islet transplantation, but mandate stringent selection criteria (controlled setting, warm ischemia $<30 \mathrm{~min}$, cold ischemia $<4$ hours) to preserve islet potency [41, 42].

The pancreas is provided by meticulous surgery with preservation of capsular integrity. This is important for subsequent enzymatic delivery. Handling is minimized to avoid pancreatitis and local injury prior to aortic cross-clamping [43]. The pancreas is cooled rapidly with intracellular preservation solutions and topical ice, then transported to the CGMP islet isolation center. Both solutions, University of Wisconsin (UW) and histidinetryptophan-ketoglutarate (HTK), provide equivalent protection of the pancreas during transport for islet isolation, although HTK may be inferior to UW for whole pancreas transplantation preservation [44-46]. Cold ischemic times are ideally kept to below 6-8 hours where possible.

In the CGMP facility, the pancreas is trimmed, the duodenum and spleen removed, and the pancreatic duct is cannulated. Enzyme is first delivered at $4-10^{\circ} \mathrm{C}$ for 10 minutes, then warmed for 4 minutes to $37^{\circ} \mathrm{C}$ to deliver active collagenase enzyme to the islet-acinar interface $[47,48]$. The process is designed to reduce a $70-100 \mathrm{~g}$ pancreas to extract the $1-2 \%$ containing islets in as lower purity and volume as possible. A minimal islet mass of $5,000 \mathrm{IEQ} / \mathrm{kg}$ is generally required for each transplant, and $>6,000-7,000 \mathrm{IEQ} / \mathrm{kg}$ for single-donor success. An inability to extract highyield, high-potency human islets was a formidable challenge in the early 1980's, and precluded success in early clinical trials. Ricordi's automated method revolutionized the process. It involves the sectioning of the distended pancreas into several large pieces, and transfer to a chamber containing steel marbles and a $500 \mu \mathrm{m}$ mesh screen [10]. The enzymatic solution recirculates at $37^{\circ} \mathrm{C}$ for as long as it takes (typically 15-30 minutes) to free islets from their surrounding matrix. Serial samples are stained with dithizone to determine the optimal time-point to dilute and cool the process $[49,50]$.

A major key factor to successful islet isolation is the quality, specificity, and stability of the collagenase enzymatic blend used. Liberase HI (Roche Diagnostic Pharmaceuticals, Indianapolis, USA) was a major advance over previous products, but was discontinued based on potential but infinitesimally small concern of transmission of Creutzfeld-J acob related prion disease [51]. Alternative, and more optimal blends have been developed, including Serva neutral protease NB1 (Serva Electrophoresis GmbH, Heidel berg, Germany) [33, $52,53]$. Kin et al. found that separation of NB-1 and neutral protease components, with ductal de- 
livery of NB-1 and neutral protease added subse quently during recirculation, led to less enzymatic degradation and more potent yields [54]. A Liberase Mammalian Tissue Free blend (MTF, Roche Diagnostics Inc., USA) has since been released, and has optimal digestion kinetics similar to NB-1 [33]. A further enzymatic blend called Vitacyte HA (Vitacyte LLC, Indianapolis, USA), has been blended with controlled component activity for less class II degradation, and is being further evaluated presently [55].

After digestion and serial wash steps, the digest is purified using density-gradient separation on refrigerated COBE 2991 cell processors [56, 57]. The duration of centrifugation is 10 minutes. Discontinuous Ficoll gradients were used previously, but Hering et al. introduced continuous iodixanol gradients (Optiprep, Axis-Shield, Oslo, Norway) to increase efficiency, and to reduce inflammation $[35,58]$. The combination of iodixanol with University of Wisconsin preservation solution increases the differential density between exocrine and islet tissue, further supporting the enrichment process [59]. Repeating the purification run as a 'rescue gradient' may additionally augment islet recovery [60-62].

After further wash and recombination steps, this islet preparation is maintained in culture for 24-72 hours before release and clinical transplantation. The culture step improves purification as contaminating exocrine tissue survives poorly in culture. $10-20 \%$ of the islet mass is lost during culture, but a reduced state of inflammation in the final product reduces early innate and adaptive immune events, and those marginal islets likely would not engraft in the recipient. Islet culture at $24^{\circ} \mathrm{C}$ was previously shown to reduce $\mathrm{MHC}$ antigen expression [63]. Addition of insulin, transferrin, zinc, selenium, and pyruvate to CMRL-based culture media (Miami Media) supplemented by nicotinamide [64], and recently modified by the Lille group, further optimizes islet survival in culture [65-67]. The culture period also provides an important opportunity to transfer the islet recipient to the transplantation center, to condition, administer $\mathrm{T}$ cell-depletional agents, and give adjunctive anti-inflammatory agents, while avoiding exposure of newly transplanted islets to an injurious cytokine storm [31, 68-73]. If islets are to be shipped from a remote CGMP facility to a distant clinical transplantation site, the obligate culture is helpful, concentrating skill and expertise locally and minimizing costs associated with isolation [7476].
Before transplantation, the final islet preparation must meet all 'product release criteria', which include:

1. Sterility (absence of bacteria on gram stain, low endotoxin content $<5 \mathrm{EU} / \mathrm{kg}$ ), with final post hoc cultures available by 14 days

2. Potency (static insulin release stimulation index $>1.0)$

3. Volume (packed volume $\leq 5.0 \mathrm{cc}$ or settled volume $\leq 7.5 \mathrm{cc})$

4. Purity ( $\geq 30 \%$ based on dithizone staining)

5. Viability $(\geq 70 \%$ on membrane integrity dye exclusion staining with fluorescein diacetate/propidium iodide or Syto green)

6. Minimal islet mass $(\geq 5,000 \mathrm{IEQ} / \mathrm{kg}$ for routine initial transplants, $\geq 6,000 \mathrm{IEQ} / \mathrm{kg}$ for single-donor protocols, and $\geq 4,000 \mathrm{IEQ} / \mathrm{kg}$ for retransplants)

7. Compatibility (identical or compatible ABO blood, negative cytotoxic cross-match if panel reactive antibody (PRA) $>10-15 \%$ ).

The product release criteria are minimal criteria needed to transplant, but the FDA has emphasized a need to develop predictive islet potency assays to correlate with clinical efficacy. Alternative options include high-throughput kinetic flux imaging for beta-cell potency [77], laser scanning cytometry for cellular composition and mitochondrial apoptosis [78], and oxygen consumption rates, as developed by Papas and coworkers. These options strongly predict clinical potency and correlate closely with the bio-assay of reversal of diabetes in immunodeficient mice using small aliquots of the final product [79].

\section{Clinical islet transplantation}

\subsection{Selection of patients}

The indications for islet transplantation are summarized in Table 1. Islet transplant alone (ITA) refers to C-peptide-negative TID patients with a sufficient duration ( $>5$ years) to justify that all reasonable attempts have been made to correct refractory poor glycemic control by all other means. This requires an independent endocrinologist or diabetologist to optimize intensive insulin management and to consider insulin pump therapy and frequent glycemic monitoring, possibly including the use of a continuous glucose monitor and alarm [80]. Objective scoring of severity of hypoglycemia by questionnaire (Clark Score) [81], re- 
Table 1. Indications for islet transplantation

\begin{tabular}{|c|c|}
\hline Kind of transplantation & Indications \\
\hline $\begin{array}{l}\text { Islet transplantation alone } \\
\text { (ITA) }\end{array}$ & $\begin{array}{l}\text { Type } 1 \text { diabetes, duration }>5 \text { years } \\
\text { Age }>18 \text { years, weight }<90 \mathrm{~kg} \text {, insulin requirement }<1.0 \mathrm{U} / \mathrm{kg} / \text { day } \\
\text { Absence of malignancy or untreated infection } \\
\text { Ability to comply with immunosuppression and close follow-up } \\
\text { Refractory hypoglycemia or lability despite: } \\
\text { 1. Optimal intensive insulin or insulin pump with appropriate monitoring } \\
\text { 2. Supervision by a diabetologist or endocrinologist } \\
\text { 3. Increased hypoglycemic risk, evidenced by at least one of the following criteria: } \\
\text { i) Clarke score } \geq 4 \\
\text { ii) HYPO score } \geq 1000 \\
\text { iii) Lability index ( } \mathrm{LI}) \geq 400 \\
\text { iv) Combined } \mathrm{HYPO} \geq 400 \text { and } \mathrm{LI} \geq 300\end{array}$ \\
\hline $\begin{array}{l}\text { Islet after kidney (IAK) } \\
\text { transplantation }\end{array}$ & $\begin{array}{l}\text { Type } 1 \text { diabetes, successful prior renal allograft } \\
\text { Tolerating maintenance immunosuppression } \\
\text { Prednisone } \leq 5 \mathrm{mg} / \text { day } \\
\text { Absence of BK virus, or other active opportunistic infection } \\
\text { Non-sensitized (PRA }<20 \% \text { ) }\end{array}$ \\
\hline
\end{tabular}

Legend: The Clarke method [81] comprises eight questions characterizing the participant's exposure to episodes of moderate and severe hypoglycemia ( $0=$ no hypoglycemia, $\geq 4=$ hypoglycemia unawareness). The HYPO score is a composite measure of the severity of the problem based on 4 weeks of records and a year historical review of the number of episodes of severe hypoglycaemia [36]. Once measures in the general diabetes population, the HYPO score median was 143, 25th to 75th interquartile range 46-423, and the 90th centile 1047. The lability index (LI) is calculated based on changes in glucose levels over time, using 4 weeks of glucose records, and compared with a clinical assessment of glycemic lability [36]. BK Brennan-Krohn, PRA - panel reactive antibody.

view of glycemic records and symptoms (Ryan HYPO score), and assessment of glycemic excursions (Lability Index) have been hel pful in screening for potential candidates [36].

By contrast, selection of islet after kidney (IAK) patients is more straightforward, as the decision to initiate immunosuppression and accept that risk has already been pre-empted by the prior kidney transplant. If prednisone is part of the regimen, the dose should be minimized to $\leq 5 \mathrm{mg}$ per day. Screening for Brennan-Krohn (BK) virus, named after the first kidney patient to have polioma virus isolated from urine in 1971, is especially important where depletional T cell induction is given for the subsequent islet transplantation, as this can markedly elevate the risk of BK nephropathy $[82,83]$.

\subsection{Intraportal access}

The portal vein may be accessed by a noninvasive percutaneous transhepatic route or by an open surgical approach. The percutaneous route is preferred, and can be accomplished safely in centers with experienced interventional radiological expertise. At the University of Alberta, $98 \%$ of the 382 procedures have been done by the percutaneous approach, with fewer than $2 \%$ requiring open surgical access. The ability to carry out islet transplantation without major surgery is the advantage of islets over whole pancreas transplantation, and makes it one of the safest and most attractive procedures in transplantation medicine.

The percutaneous approach was first described by Weimar et al. who combined CT and fluoroscopy [84]. The Edmonton group used combined ultrasound and fluoroscopy for their initial sevenpatient study [18]. The use of preliminary color duplex ultrasonography reduces the number of capsular punctures and shortens procedural time $[85,86]$. Patients should have a normal liver parenchyma without cirrhosis or portal hypertension, and without large right-sided hemangioma. Antiplatelet agents, direct thrombin, or Xa inhibitors should be discontinued within 7-14 days of the procedure if safe to do so, or delisted if not safe. 
Patients with known thrombophilia (protein C, S, anti-thrombin III, factor $V$ Leiden deficiency) should not undergo percutaneous intraportal islet transplantation [87]. After brief skin infiltration with local anesthesia, and with ultrasonic guidance, a 22-gauge Chiba needle is advanced intraparenchymally until a peripheral branch of the right portal tree is identified [88-93]. An 18-gauge guidewire is then threaded in to the main portal vein and exchanged for a 4-5 French angio catheter (e.g. NEFF, Cook Canada, Stouffville, Ontario, Canada), with the tip positioned just above the portomesenteric confluence. A portal venogram confirms the position, and a baseline portal pressure measurement is obtained.

The final islet product, suspended in $250 \mathrm{cc}$ of transplant media in an infusion bag, is loaded with heparin (70 units/kg recipient weight) and infused under gravity [94]. If baseline portal pressure $>20$ $\mathrm{mmHg}$, or if portal pressure rises $>22 \mathrm{mmHg}$ during infusion, no further islets are given until the pressure normalizes, to avoid precipitating portal thrombosis. After completion of the transplant and rinse solution, the catheter tract is ablated with Avitene paste (Medchem Products, Woburn, Massachusetts, USA) or D-STAT (Vascular Solutions, Minneapolis, MN, USA) [95, 96]. If $1 \mathrm{~g}$ Avitene powder is mixed with 3 cc saline and 3 cc contrast media, deployment can be followed by fluoroscopy, and the goal is to generate a track of $\geq 4 \mathrm{~cm}$ in length. This approach almost completely eliminates the risk of bleeding following percutaneous access [95, 97]. A therapeutic heparin infusion is initiated in the radiology suite at 3 units $/ \mathrm{kg} / \mathrm{hr}$, then titrated to maintain a partial thromboplastin time of $60-80$ seconds, and continued for 48 hours. Low molecular weight heparin is continued for 7 days (enoxaparin $30 \mathrm{mg}$ s.c. twice daily) together with enteric-coated aspirin $81 \mathrm{mg}$ for 14 days. This approach, combined with low-volume islet products and frequent portal pressure monitoring during infusion reduces the risk of portal thrombosis, and may facilitate single-donor islet engraftment by reducing activation of the instant bloodmediated inflammatory reaction (IBMIR) $[98,99]$. Partial-branch venous occlusion of a peripheral, anterior or posterior segmental branch may occasionally occur, and carries extremely low risk of further propagation if managed with heparin/coumadin and followed with Doppler ultrasound. Complete occlusion of the entire portal tree would be the most concerning complication, but fortunately is exceedingly rare $(0 \%, 0 / 382$ transplants in Edmonton since 2000) [100].

\section{Risks with islet transplantation}

Islet transplantation is considered the safest of all organ transplantations when conducted in experienced centers, as invasive surgery is not required, and patients are not in a debilitated state requiring life-support at the time of transplantation. Thus, recovery is swift, and risk of hospitalacquired infections is extremely low. I mmunosuppressive care, monitoring, and prophylaxis remain almost identical to other solid organ transplantations. Nonetheless there are clear procedural risks of intraperitoneal bleeding, portal thrombosis, and injury to the gallbladder; the latter is avoidable if ultrasound guidance is used routinely. Inadvertent intraparenchymal cholangiography is anticipated with the 22 gauge seeker Chiba needle approach, and does not lead to bile leak [101]. As outlined above, the risks of portal thrombosis or bleeding are almost completely avoidable if the catheter tract is ablated effectively and therapeutic heparin is administered [102]. The commonest complication is mild pain or discomfort either at the catheter insertion site, or as referred pain to the right shoulder tip, is transient, occurs half of patients, is easily controlled by standard analgesic medications, and generally resolves fully in 24-48 hours. While we have encountered clinically insignificant peripheral portal branch vein occlusions unilaterally in $3.7 \%$ of the 382 islet transplantations in TID at the University of Alberta, there has been a $0 \%$ risk of complete portal occlusion. None of our patients have ever manifested signs of portal hypertension with up to 14 years of follow-up [102, 103].

Transient mild elevation in liver function has been described previously in half of the subjects, but normalizes completely by one month [104]. A 5 -fold transaminase rise was observed in $27 \%$, but also resolved within one month. Interestingly, with improved collagenase enzymes, routine adoption of islet culture protocols, and use of antiinflammatory agents at induction, the incidence and severity of observed transaminitis has diminished markedly in our more recent experience.

Hepatic steatosis has been observed in up to $20 \%$ of the cases on ultrasound and magnetic resonance liver imaging, and confirmed by biopsy on rare occasion [105-109]. The fat is macrovesicular but focal, and reflective of high local insulin release from functioning islets. These changes are reversible, have yet to be associated with sequelae of non-alcoholic steatohepatitis, and are perceived as inconsequential. 
Potential risk of hepatocellular adenoma and carcinoma has been raised by Dombrowski et al. in rats receiving low islet mass after treatment with streptozotocin, and similar changes were observed in spontaneously diabetic BB/Pfd rats [110, 111]. Fortunately, this observation appears to be unique to the rat. Of over 1,500 auto- and allo-islet transplantations carried out in humans with up to 35 years of follow-up, there has yet to be a case report of this complication in patients [21, 112-114].

The risk of transmissible infection from contaminated donor islets has been exceedingly low to date. While the risk may be low, it is well de scribed in solid organ transplantation, with transmission of hepatitis $C$, human immunodeficiency virus, fatal lymphocytic choriomeningitis, and rabies [115-118]. A fatal case of untreated West Nile Virus encephalitis has been described in one islet recipient who received two islet transplants three years previously, but this was not of donor origin [119]. Careful screening of donors with avoidance of high-risk donors for non-lifethreatening transplants is required in all cases. The period of islet culture can provide additional time to complete nuclear acid testing for HIV, hepatitis $B$ and $C$, with a plan to wait for negative results before proceeding with transplantation [120].

The risk of death following islet transplantation has been exceedingly rare. Our actuarial survival rate at the University of Alberta is $97 \%$ with 14 years of follow-up (6/183 subjects). Specifically, we have encountered no deaths as a direct or indirect consequence of immunosuppression, to the best of our knowledge. Of 6 deaths, 4 were cardiovascular from diabetic microangiopathy, coronary occlusion, or arrhythmia, 1 from fatal hypoglyce mia after a failed islet transplant and return to insulin, and 1 inadvertent overdose of methadone [121]. A mortality rate of $1.3 \%$ (18 cases including the 6 from Edmonton) has been reported in the latest CITR report. Of these, 3 were possibly linked and only 1 definitely related to islet transplantation or immunosuppression [19]. Conversely, over a similar time period, several cases of death from severe hypoglycemia have been noted in patients on waiting lists for islet transplantation who never received therapy. This suggests risk equipoise between islet transplantation and poorly controlled T1D, and would further support the need for a randomized controlled trial to quantify the risk-benefit balance more precisely.

In terms of malignancy, the CITR registry highlights 13 patients with treatable skin basal or squamous cell carcinoma, with an overall rate of
$2.3 \%$ [19]. These are likely resultant from chronic immunosuppression. Interestingly, the drug sirolimus may be protective in this regard [122-131].

The risk of HLA sensitization has been raised previously by our group, but only in a small subset of patients with failed islet transplants who became C-peptide-negative and were withdrawn from immunosuppression, with an overall risk of $16 \%$ [132]. Our more recent experience with potent $\mathrm{T}$ cell-depletional induction with alemtuzumab has been associated with exceedingly low rates of PRA sensitization. The Geneva group also reported low rates of HLA sensitization (10.8\% risk) in islet after kidney recipients [133].

\section{Immunosuppression for islet trans- plantation}

Immunosuppression for clinical islet transplantation must consistently suppress both autoand alloreactivity, and for this to be achieved, threshold therapeutic drug levels and dosing must be sustained at all times. In contrast to all other solid organ transplants, this small-volume endocrine graft is widely dispersed throughout the liver, and the only surrogate marker of dysfunction, hyperglycemia, is usually an end-stage response to irreversible graft injury. Only on rare occasion, islet grafts have been rescued from acute cellular or humoral rejection by interventional treatment with corticosteroids or rituximab and intravenous immunoglobulin [134, 135].

Recurrent autoimmunity in T1D was incorrectly assumed to be readily controlled by standard immunosuppression, perhaps driven by preliminary encouraging data from the early cyclosporine intervention trials in new-onset T1D [136]. Another evidence for this assumption was provided by the observation that recurrent autoimmunity led to rapid islet destruction in an identical twin recipient of a segmental pancreas transplant in the absence of immunosuppression [137], while pancreas allografts functioned well in thousands of other recipients with T1D receiving immunosuppression [138]. Burke et al. have clearly documented several cases of recurrent autoimmunity arising in whole pancreas transplantations, despite maintenance of therapeutic levels of immunosuppression [139]. Rossini et al. demonstrated evidence of recurrent autoimmunity after intraportal islet transplantation under the Edmonton Protocol, with liver biopsies showing surviving islets, but with specific destruction of betacells [140]. 
Finding immunosuppressive cocktails that more effectively suppress autoimmunity in humans is especially challenging as the only experimental model, the non-obese diabetic (NOD) mouse, has a flawed immune system, and consistently fails to reflect clinically relevant response $[141,142]$. F ortunately, advances by Roep and the Leiden group in peripheral blood monitoring of $T$ cell autoreactivity against insulinoma-associated protein 2 (IA2A) and glutamic acid decarboxylase (GADA), with strong correlation with islet outcome, suggest that such tools may help guide future specific therapeutic suppression of autoimmunity $[23,143]$.

The added challenge is that most of the immunosuppressive agents in common use in transplantation are directly toxic to beta-cells, and this is compounded when islets are transplanted intraportally and exposed to high local drug levels [144-146]. Using lineage tracing techniques, Nir et al. demonstrated that both tacrolimus and sirolimus, drugs used in the Edmonton Protocol, are potent inhibitors of beta-cell regeneration in mice [147].

\subsection{Induction of immunosuppression}

T cell-depletional induction strategies are being used increasingly in islet transplantation as long-term results appear more durable with this approach [21, 148, 149]. Previous use of the antiIL2R monoclonal antibodies ( $\mathrm{mAb}$ ) daclizumab and basiliximab were well tolerated without side effects in the Edmonton Protocol, but probably add little additional allograft protection, and minimal if any protection against T1D autoimmunity. Large-scale clinical trials of daclizumab and mycophenolate mofetil (MMF) in new-onset T1D failed to preserve beta-cell function or prolong the honeymoon period [150]. Hering et al. promoted the use of $\mathrm{T}$ cell-depletional or modulatory agents for their single-donor islet transplant series, and a large number of preclinical studies support their use as a means to facilitate autoimmune regulation and tolerance [35, 151-158]. Bellin et al. analyzing the Minnesota and CITR islet data, found that $\mathrm{T}$ cell-depletional induction, especially in combination with tumor necrosis factor alpha (TNFalpha) blockade, provided the most durable $50 \%$ insulin independence rates at five years posttransplant [148].

Thymoglobulin (rabbit ATG) is given as a cumulative dose of $6 \mathrm{mg} / \mathrm{kg}$ by peripheral intravenous infusion over $2-3$ days, and at least $2 \mathrm{mg} / \mathrm{kg}$ is infused prior to islet infusion [35]. In Edmonton, we currently favor $T$ cell-depletional induction with alemtuzumab, $30 \mathrm{mg}$ by peripheral i.v. over 3 hours, based on superior potency, tolerability, sustained effect, and cost. To minimize dose-related side effects, acetaminophen $650 \mathrm{mg}$ p.o., diphenhyrdramine $50 \mathrm{mg}$ i.v. and solumedrol $250 \mathrm{mg}$ i.v. are given 30 minutes prior to alemtuzumab. Alemtuzumab was first tested in renal transplantation by Calne et al. in a propetolerance approach together with low-dose cyclosporine [159-161]. Alemtuzumab generally requires maintenance therapy with calcineurin inhibitors. Maintenance monotherapy sirolimus is associated with high rates of rejection in kidney, and in our previous experience in islet transplantation [162-165]. Therefore, we recommend tacrolimus (target trough $10 \mathrm{ng} / \mathrm{ml}$ for 3 months, then 8-10 $\mathrm{ng} / \mathrm{ml}$ ) together with MMF up to $2 \mathrm{~g}$ per day in divided dose as tolerated thereafter, as this has provided superior insulin independence rates at 5 years.

We have observed increased rates of late CMV transmission and reactivation with the use of either thymoglobulin or alemtuzumab T-depletional induction, despite the use of early CMV prophylaxis, but these have been largely sub-clinical and without sequelae [166-168]. Valganciclovir is recommended for all subjects receiving T-depletional therapies, irrespective of donor and recipient mismatch status, given at $450 \mathrm{mg}$ daily for 14 days, then increased to $900 \mathrm{mg}$ daily for 12 weeks posttransplant [166]. Sulphamethoxazole $400 \mathrm{mg}$ and trimethoprim $80 \mathrm{mg}$ is given once daily for 6 months for Pneumocystis jiroveci prophylaxis. If allergic to sulphonamide, it may be substituted with monthly pentamidine inhalations (300 mg).

\subsection{Anti-inflammatory and beta-cell-pre serving strategies}

Based on Hering et al., most centers have adopted the use of anti-TNFalpha blockade in the peritransplant period [35, 148, 153]. Farney et al. initially described this approach in mice [169]. Etanercept is given as $50 \mathrm{mg}$ i.v. pre-transplant, then $25 \mathrm{mg}$ S.C. on days 3,7 , and 10 posttransplant [35]. We recently found strong potentiation of marginal mass human islet engraftment in immunodeficient mice when etanercept is combined with an anti-ILI beta receptor antibody, anakinra [170]. Matsumoto et al. suggested that this combination might be beneficial in a small series of islet recipients [171]. At present, this combination is being explored in an expanded series in Edmonton. 
Korsgren's group in Sweden have explored a series of strategies designed to decrease an innate immune injury to islets (IBMIR) triggered through islet expression of tissue factor, leading to platelet aggregation, inflammation, and injury [172, 173]. Circulating thrombin-antithrombin complex and C-peptide release from islet lysis correlating with the IBMIR response, and acute loss of labeled human islets detected by positron emission tomography, confirm a major role for this pathway in limiting islet engraftment and survival [174, 175]. Peritransplant insulin and heparin may partially modify the response [99], but more potent strategies are being tested, including surface binding of heparin to islets [176], low molecular weight dextran, and direct thrombin inhibitors. Balancing risk of bleeding against improved islet engraftment and survival will be critical as these strategies move forward.

Our basic laboratory has been interested in the control of islet apoptosis as a means to augment initial islet survival. Using a spectrum of different pan-caspase inhibitor compounds, we consistently demonstrated in predinical models that in the presence of these agents, only $10-30 \%$ of the usual marginal islet engraftment mass was required to reverse diabetes with mouse, pig, and human islets, when given for just two weeks during the early islet engraftment period [177-182]. One agent (IDN-6556, Conatus Pharmaceuticals Inc., San Diego, USA) appeared to be most promising in a large animal pig islet autograft model [183], and has now moved to early pilot clinical trials in Edmonton.

Glucagon-like peptide 1 (GLP-1) analogues, especially exenatide, have been explored extensively by the Miami, Vancouver, and Illinois groups, as a means to facilitate both single-donor and supplemental islet engraftment [184-190]. These agents need to be continued indefinitely to maintain improved metabolic control in islet transplantation. Up to one third of patients cannot tolerate exenatide due to severe nausea. We have tested an alternative, long-acting once-daily GLP-1 analogue, liraglutide, as this agent has had much lower rates of nausea and intolerance in trials in type 2 diabetes. Liraglutide improves marginal mass human islet engraftment in mice, protects against immunosuppressant related beta-cell toxicity [191], and when tested in a large animal pig autotransplant model, liraglutide helped to resist metabolic graft failure over time [192]. When added to human islets in culture $(1 \mu \mathrm{M} / \mathrm{l})$, liraglutide improved islet recovery and engraftment in mice [193]. Novo Nordisk is currently conducting a 16-center international placebo-controlled RCT to further evaluate these findings in the clinic [194].

\subsection{Maintenance immunosuppression}

The choice of maintenance immunosuppressive agents has been especially challenging in clinical islet transplantation. The therapy must be sufficiently potent to suppress auto- and alloimmunity, safe, well tolerated and 'islet friendly' to avoid beta-cell toxicity [21, 144]. The added risk of nephrotoxicity is a particular challenge, as patients with longstanding T1D have underlying nephropathy, and are at increased risk of renal failure $[195,196]$. The Edmonton Protocol reduced calcineurin inhibitor $(\mathrm{CNi})$ exposure through the use of high-dose sirolimus (levels $12-15 \mu \mathrm{g} / \mathrm{l}$ for 3 months, then 10-12 $\mu \mathrm{g} / \mathrm{l}$ ) [18]. While high rates of one-year insulin independence were observed in Edmonton and other leading islet centers [197], it became apparent that high-dose sirolimus was difficult to titrate when extended to an international multicenter trial [198-200]. High rates of mouth ulceration [100, 101], ovarian cysts [201-203], fatigue, diarrhea, occasional severe small bowel ulceration [204], pneumonitis [205], edema [108, $206]$, and proteinuria $[207,208]$ have made this approach less attractive. We have largely abandoned the use of sirolimus at the University of Alberta for islet transplantation, finding that higherdose tacrolimus and MMF are far better tolerated [121]. We have observed a substantial improvement in five-year insulin independence with alemtuzumab induction and tacrolimus/MMF maintenance, suggesting that this strategy provides adequate immunoprotection and function in practice, despite theoretical concerns of islet toxicity.

Strategies that eliminate $\mathrm{CNi}$ entirely while providing ongoing immunosuppressive protection have become a major priority in the field of islet transplantation. Posselt et al. found that thymoglobulin induction and monthly maintenance costimulation blockade infusion with belatacept provided an effective $\mathrm{CNi}$-free regimen requiring only sirolimus or MMF [38]. Posselt et al. and Turgeon et al. have both explored an anti-leukocyte functional antigen-1 antibody (anti-LFA1 mAb, efalizumab) in place of costimulation blockade [38, 209]. While encouraging, these observations are limited to a small number of patients, and the anti-LFA1 mAb has been withdrawn due to exceedingly low rates of progressive multifocal leukoencephalopathy in psoriasis patients (3 confirmed cases and an additional case suspected in > 
Table 2. Centers with five-year insulin independence rates $>50 \%$

\begin{tabular}{lllll}
\hline Center & Approach & 5-year rate & Year & Reference \\
\hline M innesota & Anti-CD3 + etanercept & $70 \%$ (at 7 yr)* & 2011 & Hering et al. [35, 152] \\
M innesota CITR & T cell depletion + anti-TN F & $50 \%$ & 2012 & Bellin et al. [148] \\
Edmonton & Alemtuzumab +Tac + M M F +anakinra +etanercept & $60 \%$ & 2012 & Shapiro et al. [21, 121] \\
UCSF & ATG + efalizumab/ belatacept +SRL or M M F & $80 \%($ at 4 yr)* & 2012 & Posselt et al. [38] \\
UIC & Tac/ SRL or M M F + exenatide +etanercept & $60 \% *$ & 2012 & Gangemi et al. [190] \\
Lille, France & Tac/ SRL & $50 \% *$ & 2012 & Vantyghem et al. [142] \\
Geneva, GRACIL & ATG +Tac/ SRL & $50 \% *$ & 2012 & Berney et al. [142] \\
\hline
\end{tabular}

Legend: * 5-year insulin independence data updated from previous publications in oral presentation or by personal communication, American Transplant Congress Symposium "Advances in Islet Transplantation" June 6, 2012, Boston, USA, and at the International Islet and Pancreas Transplant Association (IPITA) meeting, 2011, in Prague, Czech Republic. Abbreviations: ATG - antithymocyte globulin, CITR - Collaborative Islet Transplant Registry, M M F - mycophenolate mofetil, SRL - sirolimus, Tac - tacrolimus, TNF - tumor necrosis factor alpha, UCSF - University of California San Francisco, UIC - University of Illinois at Chicago.

46,000 treated) [210-212]. An ideal CNi-free immunosuppression is not available for more widespread and long-term testing in clinical islet transplantation at present.

\subsection{Long-term outcomes}

The five year results with the original Edmonton Protocol demonstrated a steep loss of insulin independence by the third year, but persistent Cpeptide and ongoing long-term protection from hypoglycemia in most treated patients [213]. The cause for inexorable loss of complete insulin independence over time is likely multifactorial, but re current autoimmunity and allograft rejection are major causes, exacerbated by a marginal initial engraftment mass.

Senior et al. updated the status of the Edmonton patients with a decade of follow-up, and of 138 patients in that analysis, $79 \%$ had full or partial graft function with correction of $\mathrm{HbAlc}$ and protection from hypoglycemia, and current protocols provided $60 \%$ insulin independence beyond 4 years [121]. Similar results have been reflected in the CITR database [214]. This remarkable level of glycemic stabilization is rarely achieved by insulin pumps or by continuous glycemic monitoring.

The encouraging news that more potent induction and maintenance immunosuppression, combined with pre-emptive anti-inflammatory strategies, are having positive impact on the current five-year insulin independence rates [148, 149]. Indeed, as summarized in Table 2, there are now at least 6 independent centers, reporting $50-70 \%$ five-year rates of insulin independence with different induction and maintenance approaches [35, $151-153,215,216]$. For islet-al one transplantation, this represents a milestone advance, as the results at five years equate at least to the registry data for pancreas-alone transplantation [151, 217]. However, islet transplantation will not replace pancreas transplantation until the single-donor rates for islet transplantation improve further. Payne, Griffin, and others demonstrated, at least in small and large animals, a single-donor islet preparation could treat up to three recipients $[218,219]$. This has yet to be achieved routinely in humans, but could have major bearing on the current limited islet supply and more broader application in T1D. The first demonstration of this concept was a living donor islet transplant carried out with islets prepared from a distal pancreactomy [220].

Progress has occurred in single-donor islet engraftment, and 10 programs have reported small cohorts of patients with single-donor success (Table 3). Understanding the factors leading to increased islet potency will be essential to expanding this routinely [221]. Predictive islet potency assays (e.g. oxygen consumption rate, mitochondrial and beta-cell viability) will be an essential component in the selection of optimal islet preparations.

\section{Impact of islet transplant upon secondary complications}

It is not questioned that the restoration of near-perfect glycemic control will stabilize and potentially reverse secondary diabetic complications. 
Table 3. Single-donor islet protocols

\begin{tabular}{llll}
\hline Center & Approach & Year & Reference \\
\hline M innesota & Anti-CD3 +etanercept & 2005 & Hering et al. [35] \\
Pennsylvania & Edmonton-like & 2003 & M arkmann et al. [254] \\
Emory & Efalizumab +M M F & 2010 & Turgeon et al. [209] \\
San Francisco & ATG +efalizumab +SRL or M M F & 2010 & Posselt et al. [255] \\
San Francisco & ATG + belatacept +SRL or M M F & 2010 & Posselt et al. [38] \\
Edmonton & Peritransplant insulin +heparin & 2010 & Koh et al. [99] \\
Kyoto & Living donor islet transplant & 2005 & M atsumoto et al. [220] \\
Baylor & ATG +anakinra +etanercept & 2011 & M atsumoto et al. [256] \\
Vancouver & Exenatide & 2007 & Ghofaili et al. [189] \\
M iami & Exenatide & 2009 & Faradji et al. [184] \\
UIC & Exenatide & 2008 & Gangemi et al. [190] \\
\hline
\end{tabular}

Legend: ATG - antithymocyte globulin, M M F - mycophenolate mofetil, SRL - sirolimus, UIC - University of Illinois at Chicago.

Such degree of control is rarely if at all achievable with subcutaneously injected insulin. Intensive insulin is clearly superior to standard management, but is far from perfect, and the more intensive the administration, the higher the risk of severe and recurrent hypoglycemia. These are the hard lessons learned from the DCCT registration trials of intensive insulin therapy [222, 223]. In whole pancreas transplantation, the near-perfect glycemic control achieved has had major benefit in stabilizing coronary artery disease, intimal carotid thickness, diabetic glomerulopathy, neuropathy, retinopathy, and other secondary complications of T1D, and decreases cardiovascular mortality [224236].

Compelling data is emerging in islet transplantation providing a similar protective impact. The Milan group showed that positive C-peptide can stabilize both macro- and microangiopathic changes in T1D, irrespective of the insulin independence status [237-243]. The Vancouver group conducted a prospective cohort crossover study, comparing the intervention of islet transplantation with optimal medical therapy, and found reduced progression of retinopathy and a trend towards improved nerve conduction velocity [244, 245]. Despite the presence of $\mathrm{CNi}$, there was a reduced decline in renal function [244]. Danielsen et al. found that a surrogate marker of atherosclerosis, carotid intimal thickness, was significantly reduced after 12 months of insulin independence, but emphasized a need for multimodal management to achieve this, including optimal management of hy- perlipidemia and hypertension [246]. Large-scale RCTs without crossover are needed to corroborate these important positive findings.

\section{Alternatives to islet transplanta- tion}

While islet transplantation remains an attractive therapy, it is acknowledged that transplant tolerance, or stem-cell derived and xenogeneic islets are not on the proximate horizon [247]. Alternative means to stabilize glucose control are being explored, including high-tech closed loop insulin pumps and implantable sensor technologies that may serve as bridge or destination therapy, avoiding a need for transplantation entirely. Such approaches may still be cumbersome for patients, and glycemic monitoring and insulin delivery in the subcutaneous site may still suffer from the challenges of depot injection, delayed absorption, and imperfect dynamic matching for perfect moment-to-moment control which is attainable in the native pancreas or from transplanted islets.

Several strategies for prevention and early intervention in TID have met with recent disappointment, despite enormous promise generated in mouse models, as discussed in other articles in this current Special I ssue. Shoda et al. pointed out that over 463 interventional treatments have been shown to prevent or reverse autoimmune diabetes in NOD mice [142]. Attempts to move these to the clinic have met with frustration despite large-scale clinical enrollment and major cost [248]. The NOD 
mouse model clearly has major limitations as a surrogate for clinical autoimmune T1D. Better models or empiric interventions that clearly work in patients are now needed. Voltarelli et al. developed an approach in Brazil for 'immunological re set' designed to eliminate autoreactive lymphocyte clones using non-myeloablative autologous hematopoetic stem cell transplantation [249-251]. Of 20 new-onset T1D subjects, 12 were rendered insulin independent for 31 months, but there were side effects from opportunistic infection and oligospermia resultant from heavy immune conditioning with thymoglobulin and cyclophosphamide. If these approaches can be further modified to improve the safety profile, while restoring more permanent self-tolerance, they would obviate a need for cellular replacement therapy.

\section{Summary and conclusions}

Islet transplantation has moved forward from a state of experimental curiosity in mice to a robust therapy for highly selected patients with T1D, refractory to stabilization by alternate means. This remarkable progress has occurred over a span of 40 years, and could not have occurred without extensive dynamic international collaboration. Currently, more than 1,000 patients have received islet transplants since the Edmonton Protocol series was reported in 2000 . The long-term results of islet transplantation in selected centers now match the registry data for pancreas-alone transplantation, with 6 sites reporting five-year insulin independence rates $\geq 50 \%$.

I slet transplantation has been criticized for the use of multiple donor pancreas organs, but progress has occurred in single-donor success, with 10 sites reporting increased single-donor engraftment. The next wave of innovative clinical trial interventions will address IBMIR, apoptosis, and inflammation, and will translate to further marked improvement in single-donor success. Effective control of auto- and alloimmunity is the key to long-term islet function, and high-resolution cellular and antibody-based assays will add considerable precision to this process. Advances in immunosuppression, with new antibody-based targeting of costimulatory blockade and other T-B cellular signaling, will have further profound impact on the safety record of immunotherapy.

Islet transplantation is one of the safest of all organ transplantation procedures, and an ability to deliver cells by a non-surgical low-risk approach is an important attraction of this therapy. Clinical trials will move forward shortly to test out new human stem cell-derived islets, and in parallel, trials will move forward testing pig islets for compatibility in patients. Induction of immunological tolerance to self-islet antigens and to allografts is a difficult challenge, but potentially within our grasp. Ultimately, strategies to prevent T1D, and induce self-regeneration of islets within the native pancreas would replace the need for cellular transplantation entirely. More intensive research is needed to address these avenues.

Acknowledgments: AMJ S is supported by the $\mathrm{Na}$ tional Institutes of Health $(\mathrm{NIH})$, Clinical Islet Transplant Consortium $(\mathrm{CIT})$, jointly funded by the National Institutes of Allergy, Immunology and Infectious Disease (NIAID) and the National Institute of Diabetes and Digestive and Kidney Diseases (NIDDK). He is a senior clinical scholar at Alberta Innovates Healthcare Solutions (AIHS). He receives grant support from the J uvenile Diabetes Research F oundation (J DRF). The clinical islet transplant program at the University of Alberta receives support from Alberta Health Services, the Government of Alberta, and through the Diabetes Research Institute Foundation of Canada (DRIFCan).

Disclosure: The author declares that two book chapters were recently submitted, covering a similar topic, and while the current manuscript is distinct, there is inevitable overlap of material between these publications [1, 2]. No other relevant conflicts of interest exist.

\section{R eferences}

1. Shapiro AM, Rocirdi C. Islet cell transplantation - indications, risks and long-term outcomes. In: Kirk AD (editor). Textbook of organ transplantation. W iley-Blackwell, 2013, in press.

2. Shapiro AM, Rocirdi C. The transplant procedure and surgical technique: islet transplantation. In: Kirk AD (editor). Textbook of organ transplantation. W iley-Blackwell, 2013, in press.

3. O'R eilly M, O'Sullivan EP, Davenport $C$, Smith $D$. "D ead in bed": a tragic complication of type 1 diabetes mellitus. Irish J M ed Sd 2010. 179(4):585-587.

4. Koltin D, Daneman D. D ead-in-bed syndrome - a diabe-

tes nightmare. Pediatr D iabetes 2008. 9(5):504-507.

5. Hanas R. Dead-in-bed syndrome in diabetes mellitus and hypoglycaemic unawareness. Lancet 1997. 350(9076):492493.

6. Campbell LK, Gonder-Frederick LA, Broshek DK, Kovatchev BP, Anderson S, Clarke WL, Cox DJ. $\mathrm{N}$ eurocognitive differences between drivers with type 1 diabetes with and without a recent history of recurrent driving mishaps. Int J D iabetes M ellit 2010. 2(2):73-77.

7. Williams $\mathbf{P}$. N otes on diabetes treated with extract and by grafts of sheep's pancreas. B M J 1894. 2:1303.

8. Ballinger WF, Lacy PE. Transplantation of intact pancreatic islets in rats. Surgery 1972. 72(2):175-186.

9. Ballinger WF, Lacy PE, Scharp DW, Kemp CB, 
Knight M. I sografts and allografts of pancreatic islets in rats. B r J Surg 1973. 60(4):313.

10. Ricordi C, Lacy PE, Scharp DW. Automated islet isolation from human pancreas. D iabetes 1989. 38(Suppl 1):140142.

11. Robertson GS, Chadwick DR, Contractor H, James RF, Bell PR, London NJ. The use of continuous density gradients for the assessment of islet and exocrine tissue densities and islet purification. A da D iabetol 1993. 30(3):175-180.

12. Yamamoto $\mathbf{T}$, Horiguchi $A$, Ito $\mathbf{M}, \mathbf{N}$ agata $\mathbf{H}$, Ichii H, Ricordi C, Miyakawa S. Q uality control for clinical islet transplantation: organ procurement and preservation, the islet processing facility, isolation, and potency tests. J H epatobiliary Pancreat Surg 2009. 16(2):131-136.

13. Scharp DW, Lacy PE, Santiago JV, McCullough CS, Weide LG, Falqui L, Marchetti P, Gingerich RL, Jaffe AS, Cryer PE, et al. Insulin independence after islet trans plantation into type I diabetic patient. Diabetes 1990. 39(4):515-518.

14. Najarian JS, Sutherland DE, Baumgartner D, Burke B, R ynasiewicz JJ, Matas AJ, Goetz FC. T otal or near total pancreatectomy and islet autotransplantation for treatment of chronic pancreatitis. Ann Surg 1980. 192(4):526542.

15. Tzakis AG, Ricordi C, Alejandro R, Zeng Y, Fung J,, Todo S, Demetris AJ, Mintz DH, Starzl TE. Pancreatic islet transplantation after upper abdominal exentera tion and liver replacement. $L$ ancet 1990. 336(8712):402-405.

16. Ricordi C, Tzakis AG, Carroll PB, Zeng YJ, Rilo $H L$, Alejandro R, Shapiro A, Fung JJ, Demetris AJ, Mintz DH, et al. H uman islet isolation and allotransplantation in 22 consecutive cases. T ransplantation 1992. 53(2):407414.

17. Bretzel RG, Brandhorst D, Brandhorst H, Eckhard M, Ernst W, Friemann S, Rau W, Weimar B, Rauber K, Hering BJ, et al. Improved survival of intraportal pancreatic islet cell allografts in patients with type- 1 diabetes mellitus by refined peritransplant management. J $\mathrm{M} \mathrm{ol} \mathrm{M}$ ed 1999. 77(1):140-143.

18. Shapiro AM, Lakey JR, R yan EA, Korbutt GS, T oth E, Warnock GL, Kneteman NM, Rajotte RV. I slet transplantation in seven patients with type 1 diabetes mellitus using a glucocorticoid-free immunosuppressive regimen. $\mathrm{N}$ Engl J M ed 2000. 343(4):230-238.

19. Center CC. Seventh Annual R eport Collaborative Islet Transplant R egistry R ockville, MD: Collaborative Islet T ransplant R egistry. December 30, 2011:1-186. Available from:

https:// web.emmes.com/ study/ is// reports/ 01062012 7thAnnualR eport.pdf

20. Ricordi $\overline{\mathbf{C}}$, Strom TB. Clinical islet transplantation: advances and immunological challenges. $\mathrm{N}$ at $\mathrm{Rev}$ Immunol 2004. 4(4):259-268.

21. Shapiro AM. State of the art of clinical islet transplantation and novel protocols of immunosuppression. C urr Diabetes Rep 2011. 11(5):345-354.

22. Hathout E, Lakey J, Shapiro J. I slet transplant: an option for childhood diabetes? A rch D is C hild 2003. 88(7):591-594.

23. Huurman VA, Hilbrands R, Pinkse GG, Gillard P, Duinkerken $G$, van de Linde $P$, van der Meer-Prins PM, Versteeg-van der Voort Maarschalk MF, Verbeeck K, Alizadeh BZ, et al. C ellular islet autoimmunity associates with clinical outcome of islet cell transplantation. Plos 0 ne 2008. 3(6):e2435.
24. Huurman VA, van der Torren CR, Gillard P, Hilbrands $R$, van der Meer-Prins EP, Duinkerken $G$, Gorus FK, Claas FH, Keymeulen B, Roelen DL, et al. Immune responses against istet allografts during tapering of immunosuppression - a pilot study in 5 subjects. Clin Exp Immunol 2012. 169(2):190-198.

25. Han D, Xu X, Baidal D, Leith J, Ricordi C, Alejandro R, Kenyon NS. Assessment of cytotoxic lymphocyte gene expression in the peripheral blood of human islet allograft recipients: elevation precedes clinical evidence of rejection. D iabetes 2004. 53(9):2281-2290.

26. Lakey JR, Warnock GL, Rajotte RV, SuarezAlamazor ME, Ao Z, Shapiro AM, Kneteman NM. $V$ ariables in organ donors that affect the recovery of human islets of Langerhans. T ransplantation 1996. 61(7):1047-1053.

27. Kaddis JS, Danobeitia JS, Niland JC, Stiller T, Fernandez LA. M ulticenter analysis of novel and established variables associated with successful human islet isolation outcomes. A m J T ransplant 2010. 10(3):646-656.

28. Liu X, Matsumoto S, Okitsu T, Iwanaga $Y$, Noguchi $H$, Y onekawa $Y$, Nagata $H$, Kamiya $H$, Ueda $M$, $\mathbf{H}$ atanaka $\mathbf{N}$, et al. A nalysis of donor- and isolation-related variables from non-heart-beating donors (N H BD s) using the K yoto islet isolation method. C ell T ransplant 2008.17(6):649656.

29. Hanley SC, Paraskevas S, Rosenberg L. Donor and isolation variables predicting human islet isolation success. T ransplantation 2008. 85(7):950-955.

30. Nano R, Clissi B, Melzi R, Calori G, Maffi P, Antonioli B, Marzorati S, Aldrighetti L, Freschi M, Grochowiecki $\mathbf{T}$, et al. I slet isolation for allotransplantation: variables associated with successful islet yield and graft function. D iabetologia 2005. 48(5):906-912.

31. Fraker C, Montelongo J, Szust J, Khan A, Ricordi C. The use of multiparametric monitoring during islet cell isolation and culture: a potential tool for in-process corrections of critical physiological factors. C ell Transplant 2004. 13(5):497-502.

32. Kin T, O'Gorman D, Schroeder A, Onderka C, Richer B, Rosichuk S, Z hai X, Shapiro AM. H uman islet distribution program for basic research at a single center. T ransplant P roc 2011. 43(9):3195-3197.

33. O'Gorman D, Kin T, Imes S, Pawlick R, Senior $\mathbf{P}$, Shapiro AM. Comparison of human islet isolation outcomes using a new mammalian tissue-free enzyme versus collagenase N B-1. T ransplantation 2010. 90(3):255-259.

34. O'Gorman D, Kin T, Murdoch T, Richer B, McGhee-Wilson D, R yan EA, Shapiro JA, Lakey JR. The standardization of pancreatic donors for islet isolations. T ransplantation 2005. 80(6):801-806.

35. Hering BJ, Kandaswamy R, Ansite JD, Eckman PM, Nakano M, Sawada T, Matsumoto I, Ihm SH, Zhang HJ, Parkey J, et al. Single-donor, marginal-dose islet transplantation in patients with type 1 diabetes. JA M A 2005. 293(7):830-835

36. Ryan EA, Shandro T, Green K, Paty BW, Senior PA, Bigam D, Shapiro AM, Vantyghem MC. Assessment of the severity of hypoglycemia and glycemic lability in type 1 diabetic subjects undergoing islet transplantation. D iabetes 2004. 53(4):955-962.

37. Szot GL, Lee MR, Tavakol MM, Lang J, Dekovic F, Kerlan RK, Stock PG, Posselt AM. Successful clinical islet isolation using a GMP-manufactured collagenase and 
neutral protease. T ransplantation 2009. 88(6):753-756.

38. Posselt AM, Szot GL, Frassetto LA, Masharani U, Tavakol M, Amin R, McElroy J, Ramos MD, Kerlan $\mathbf{R K}$, Fong $\mathbf{L}$, et al. Islet transplantation in type 1 diabetic patients using calcineurin inhibitor-free immunosuppressive protocols based on $\mathrm{T}$-cell adhesion or costimulation blockade. T ransplantation 2010. 90(12):1595-1601.

39. Posselt AM, Szot GL, Frassetto LA, Masharani U, Stock PG. Clinical islet transplantation at the U niversity of C alifornia, San Francisco. C lin T ranspl 2010. 2010:235-243.

40. Berney T, Johnson PR. D onor pancreata: evolving approaches to organ allocation for whole pancreas versus islet transplantation. T ransplantation 2010. 90(3):238-243.

41. Markmann JF, Deng S, Desai NM, Huang X, Velidedeoglu $E$, Frank A, Liu C, Brayman KL, Lian MM, Wolf $\mathbf{B}$, et al. The use of non-heart-beating donors for isolated pancreatic islet transplantation. T ransplantation 2003. 75(9):1423-1429.

42. Saito $\mathbf{T}$, Gotoh $\mathbf{M}$, Satomi S, Uemoto $\mathbf{S}$, Kenmochi T, Itoh T, Kuroda Y, Yasunami $Y$, Matsumoto $S$, Teraoka S, et al. Islet transplantation using donors after cardiac death: report of the Japan Islet T ransplantation $\mathrm{R}$ egistry. T ransplantation 2010. 90(7):740-747.

43. Kin T, Shapiro AM. Surgical aspects of human islet isolation. Islets 2010. 2(5):265-273.

44. Paushter DH, Qi M, Danielson KK, Harvat TA, Kinzer K, Barbaro B, Patel S, Hassan SZ, O berholzer J, Wang $\mathbf{Y}$. H istidine-tryptophan-ketoglutarate and U niversity of $W$ isconsin solution demonstrate equal effectiveness in the preservation of human pancreata intended for islet isolation: a large-scale, single-center experience. C ell T ransplant 2012. In press

45. Stewart $Z A$, Cameron $A M$, Singer $A L$, Dagher $N N$, Montgomery RA, Segev DL. Histidine-tryptophanketoglutarate (HTK) is associated with reduced graft survival in pancreas transplantation. A m J T ransplant 2009. 9(1):217221.

46. Becker T, Ringe B, Nyibata M, Meyer zu Vilsendorf A, Schrem H, Luck R, Nejpp M, Klempnauer J, Bektas H. Pancreas transplantation with histidine-tryptophanketoglutarate (HTK) solution and U niversity of W isconsin (U W ) solution: is there a difference? JO P 2007. 8(3):304311.

47. Lakey JR, Warnock GL, Shapiro AM, Korbutt GS, Ao Z, Kneteman NM, Rajotte RV. Intraductal collagenase delivery into the human pancreas using syringe loading or controlled perfusion. C ell T ransplant 1999. 8(3):285292.

48. Hughes SJ, Clark A, McShane P, Contractor HH, Gray DW, Johnson PR. C haracterisation of collagen VI within the islet-exocrine interface of the human pancreas implications for clinical islet isolation? T ransplantation 2006. 81(3):423-426.

49. Kin T, Johnson PR, Shapiro AM, Lakey JR. Factors influencing the collagenase digestion phase of human islet isolation. T ransplantation 2007. 83(1):7-12.

50. Kin T. I slet isolation for clinical transplantation. Adv Exp M ed Biol 2010. 654:683-710.

51. EISaadany S, Tyshenko MG, Oraby T, Malcolm AJ, Senior P, Shapiro AM, Catford A, Salem T, Wu J, Krewski D, et al. The risk to human islet cell transplant recipients of acquiring variant Creutzfeldt-Jakob disease: a provisional quantitative risk assessment. T ransplantation 2011. 92(1):e2-4.

52. Bucher P, Mathe Z, Morel P, Bosco D, Andres A, Kurfuest $M$, Friedrich 0 , Raemsch-Guenther $N$, Buhler LH, Berney T. Assessment of a novel twocomponent enzyme preparation for human islet isolation and transplantation. T ransplantation 2005. 79(1):91-97.

53. Brandhorst $\mathbf{H}$, Friberg A, Nilsson B, Andersson $\mathbf{H} \mathbf{H}$, Felldin M, Foss A, Salmela K, Tibell A, Tufveson G, Korsgren $\mathbf{O}$, et al. Large-scale comparison of Liberase $\mathrm{HI}$ and collagenase NB1 utilized for human islet isolation. C ell T ransplant 2010. 19(1):3-8.

54. Kin T, O'Gorman D, Z hai X, Pawlick R, Imes S, Senior P, Shapiro AM. N onsimultaneous administration of pancreas dissociation enzymes during islet isolation. T ransplantation 2009. 87(11):1700-1705.

55. Caballero-Corbalan J, Friberg AS, Brandhorst $\mathbf{H}$, Nilsson B, Andersson HH, Felldin M, Foss A, Salmela K, Tibell A, Tufveson $\mathbf{G}$, et al. Vitacyte collagenase HA: a novel enzyme blend for efficient human islet isolation. T ransplantation 2009. 88(12):1400-1402.

56. Robertson GS, Chadwick DR, Contractor H, James $\mathbf{R F}$, London $\mathbf{N J}$. The optimization of large-scale density gradient isolation of human islets. A da Diabetol 1993. 30(2):93-98.

57. Swift S, Kin T, Mirbolooki M, Wilson R, Lakey JR. C omparison of cooling systems during islet purification. C ell T ransplant 2006. 15(2):175-180.

58. Mita A, Ricordi C, Messinger S, Miki A, Misawa R, Barker S, Molano RD, Haertter R, Khan A, Miyagawa $\mathbf{S}$, et al. Antiproinflammatory effects of iodixanol (O ptiPrep)-based density gradient purification on human islet preparations. C ell T ransplant 2010. 19(12):1537-1546.

59. Barbaro B, Salehi P, Wang Y, Qi M, Gangemi A, Kuechle J, Hansen MA, Romagnoli T, Avila J, Benedetti E, et al. Improved human pancreatic islet purification with the refined UIC-U B density gradient. T ransplantation 2007. 84(9):1200-1203.

60. Warnock GL, Meloche RM, Thompson D, Shapiro RJ, Fung M, Ao Z, Ho S, He Z, Dai LJ, Young L, et al. Improved human pancreatic islet isolation for a prospective cohort study of islet transplantation vs best medical therapy in type 1 diabetes mellitus. A rch Surg 2005. 140(8):735744.

61. Miki A, Ricordi C, Messinger S, Yamamoto T, Mita A, Barker S, Haetter R, Khan A, Alejandro R, Ichii H. Toward improving human islet isolation from younger donors: rescue purification is efficient for trapped islets. C ell T ransplant 2009. 18(1):13-22.

62. Ichii H, Pileggi A, Molano RD, Baidal DA, Khan A, Kuroda Y, Inverardi L, Goss JA, Alejandro R, Ricordi $\mathbf{C}$. R escue purification maximizes the use of human islet preparations for transplantation. A m J Transplant 2005. 5(1):21-30.

63. Markmann JF, Tomaszewski J, Posselt AM, Levy MM, Woehrle M, Barker CF, Naji A. The effect of islet cell culture in vitro at 24 degrees $C$ on graft survival and MHC antigen expression. Transplantation 1990. 49(2):272277.

64. Ichii H, Wang X, Messinger S, Alvarez A, Fraker C, Khan A, Kuroda Y, Inverardi L, Goss JA, Alejandro $\mathbf{R}$, et al. Improved human islet isolation using nicotinamide. A m J T ransplant 2006. 6(9):2060-2068.

65. Froud T, Ricordi C, Baidal DA, Hafiz MM, Ponte G, 
Cure P, Pileggi A, Poggioli R, Ichii H, Khan A, et al. Islet transplantation in type 1 diabetes mellitus using cultured islets and steroid-free immunosuppression: Miami experience. A m J T ransplant 2005. 5(8):2037-2046.

66. Kerr-Conte J, Vandewalle B, Moerman E, Lukowiak B, Gmyr V, Arnalsteen L, Caiazzo R, Sterkers A, Hubert T, Vantyghem MC, et al. U pgrading pretransplant human islet culture technology requires human serum combined with media renewal. Transplantation 2010. 89(9):1154-1160.

67. Clayton H, Turner J, Swift S, James R, Bell P. Supplementation of islet culture medium with insulin may have a beneficial effect on islet secretory function. Pancreas 2001. 22(1):72-74

68. Rabinovitch A, Suarez-Pinzon WL, Strynadka K, Schulz R, Lakey JR, Warnock GL, Rajotte RV. H uman pancreatic islet beta-cell destruction by cytokines is independent of nitric oxide production. J C lin E ndocrinol M etab 1994. 79(4):1058-1062.

69. Gaber AO, Fraga DW, Callicutt CS, Gerling IC, Sabek $\mathbf{O M}$, Kotb $\mathbf{M Y}$. Improved in vivo pancreatic islet function after prolonged in vitro islet culture. T ransplantation 2001.72(11):1730-1736

70. Murdoch T B, McGhee-Wilson D, Shapiro AM, Lakey JR. M ethods of human islet culture for transplantation. C ell T ransplant 2004. 13(6):605-617.

71. Berney T. Islet culture and counter-culture. Commentary on: Effect of short-term culture on functional and stressrelated parameters in isolated human islets by $\mathrm{Ihm}$ et al. T ranspl Int 2009. 22(5):531-533.

72. Daoud J, Rosenberg L, Tabrizian M. Pancreatic islet culture and preservation strategies: advances, challenges, and future outlook. C ell T ransplant 2010. 19(12):1523-1535.

73. Rabinovitch A, Sumoski W, Rajotte RV, Warnock GL. C ytotoxic effects of cytokines on human pancreatic islet cells in monolayer culture. J Clin Endocinol M etab 1990. 71(1):152-156

74. Ichii H, Sakuma Y, Pileggi A, Fraker C, Alvarez A, Montelongo J, Szust J, Khan A, Inverardi L, Naziruddin B, et al. Shipment of human islets for transplantation. A m J T ransplant 2007. 7(4):1010-1020.

75. Goss JA, Schock AP, Brunicardi FC, Goodpastor SE, Garber AJ, Soltes G, Barth M, Froud T, Alejandro R, $\mathbf{R}$ icordi C. Achievement of insulin independence in three consecutive type- 1 diabetic patients via pancreatic islet transplantation using islets isolated at a remote islet isolation center. T ransplantation 2002. 74(12):1761-1766.

76. Goss JA, Goodpastor SE, Brunicardi FC, Barth MH, Soltes GD, Garber AJ, Hamilton DJ, Alejandro R, Ricordi C. Development of a human pancreatic islettransplant program through a collaborative relationship with a remote islet-isolation center. Transplantation 2004 77(3):462-466.

77. Cabrera $\mathbf{O}$, Jacques-Silva MC, Berman DM, Fachado A, Echeverri F, Poo R, Khan A, Kenyon NS, Ricordi C, Berggren PO, et al. Automated, high-throughput as says for evaluation of human pancreatic islet function. C ell T ransplant 2008. 16(10):1039-1048.

78. Ichii H, Inverardi L, Pileggi A, Molano RD, Cabrera O, Caicedo A, Messinger S, Kuroda Y, Berggren PO, Ricordi C. A novel method for the assessment of cellular composition and beta-cell viability in human islet preparations. A m J T ransplant 2005. 5(7):1635-1645.
79. Papas KK, Colton CK, Nelson RA, Rozak PR, Avgoustiniatos ES, Scott WE, 3rd, Wildey GM, Pisania A, Weir GC, Hering BJ. H uman islet oxygen consumption rate and DN A measurements predict diabetes reversal in nude mice. A m J T ransplant 2007. 7(3):707-713.

80. R yan EA, Bigam D, Shapiro AM. Current indications for pancreas or islet transplant. D iabetes 0 bes $M$ etab 2006. 8(1):1-7.

81. Clarke WL, Cox DJ, Gonder-Frederick LA, Julian D, Schlundt D, Polonsky W. R educed awareness of hypoglycemia in adults with IDDM. A prospective study of hypoglycemic frequency and associated symptoms. Diabetes C are 1995. 18(4):517-522.

82. Gardner SD, Field AM, Coleman DV, Hulme B. N ew human papovavirus (B.K.) isolated from urine after renal transplantation. Lancet 1971. 1(7712):1253-1257.

83. Mujtaba M, Fridell J, Sharfuddin A, Kandula P, Y aqub MS, Phillips CL, Mishler D, T aber T. BK virus nephropathy in simultaneous pancreas kidney transplant: a potentially preventable cause of kidney allograft loss. C lin T ransplant 2012. 26(2):E87-E93.

84. Weimar B, Rauber K, Brendel MD, Bretzel RG, Rau WS. Percutaneous transhepatic catheterization of the portal vein: $A$ combined $C T$ - and fluoroscopy-guided technique. C ardiovasc Intervent $R$ adiol 1999. 22(4):342-344.

85. Venturini $\mathbf{M}$, Angeli $\mathbf{E}$, Maffi $\mathbf{P}$, Fiorina $\mathbf{P}$, Bertuzzi F, Salvioni M, De Cobelli F, Socci C, Aldrighetti L, Losio C, et al. Technique, complications, and therapeutic efficacy of percutaneous transplantation of human pancreatic islet cells in type 1 diabetes: the role of U S. R adiology 2005. 234(2):617-624.

86. Villiger $\mathbf{P}$, Ryan EA, Owen $\mathbf{R}, \mathbf{O}$ 'Kelly $K$, Oberholzer J, AI Saif F, Kin T, Wang H, Larsen I, Blitz SL, et al. Prevention of bleeding after islet transplantation: lessons learned from a multivariate analysis of 132 cases at a single institution. A m J T ransplant 2005. 5(12):2992-2998.

87. Brennan DC, Shannon MB, Koch MJ, Polonsky KS, Desai N, Shapiro J. Portal vein thrombosis complicating islet transplantation in a recipient with the Factor $\mathrm{V}$ Leiden mutation. T ransplantation 2004. 78(1):172-173.

88. Neeman Z, Hirshberg B, Harlan D, Wood BJ. R a diologic aspects of islet cell transplantation. C urr D iab R ep 2006. 6(4):310-315.

89. Gaba RC, Garcia-Roca R, O berholzer J. Pancreatic islet cell transplantation: an update for interventional radiologists. J V asc Interv R adiol 2012. 23(5):583-594.

90. Goss JA, Soltes G, Goodpastor SE, Barth M, Lam R, Brunicardi FC, Froud T, Alejandro R, Ricordi C. Pancreatic islet transplantation: the radiographic approach. T ransplantation 2003. 76(1):199-203.

91. Low G, Hussein N, Owen RJ, Toso C, Patel VH, Bhargava R, Shapiro AM. R ole of imaging in clinical islet transplantation. R adiographics 2010. 30(2):353-366.

92. Owen RJ, Mercer JR, Al-Saif F, Molinari M, Ashforth RA, Rajotte RV, Conner-Spady B, Shapiro AM. Portal vein embolization with radiolabeled polyvinyl alcohol particles in a swine model: hepatic distribution and implications for pancreatic islet cell transplantation. C ardiovasc I ntervent $R$ adiol 2009. 32(3):499-507.

93. O wen RJ, Ryan EA, O'Kelly K, Lakey JR, McCarthy MC, Paty BW, Bigam DL, Kneteman NM, Korbutt GS, R ajotte RV, et al. Percutaneous transhepatic pancreatic islet cell transplantation in type 1 diabetes mellitus: ra- 
diologic aspects. R adiology 2003. 229(1):165-170.

94. Baidal DA, Froud T, Ferreira JV, Khan A, Alejandro $\mathbf{R}$, Ricordi C. The bag method for islet cell infusion. C ell T ransplant 2003. 12(7):809-813.

95. Kawahara T, Kin T, Kashkoush S, Gala-Lopez B, Bigam DL, Kneteman NM, Koh A, Senior PA, Shapiro AM. Portal vein thrombosis is a potentially preventable complication in clinical islet transplantation. A m J T ransplant 2011. 11(12):2700-2707.

96. Froud T, Y rizarry JM, Alejandro R, Ricordi C. U se of D-STAT to prevent bleeding following percutaneous transhepatic intraportal islet transplantation. C ell T ransplant 2004. 13(1):55-59.

97. Kawahara T, Kin T, Shapiro AM. A comparison of islet autotransplantation with allotransplantation and factors elevating acute portal pressure in clinical islet transplantation. J H epatobiliary Pancreat Sd 2012. 19(3):281-288.

98. ohansson $\mathbf{H}$, Lukinius A, Moberg $L$, Lundgren $\mathbf{T}$, Berne C, Foss A, Felldin M, Kallen R, Salmela K, Tibell $\mathbf{A}$, et al. Tissue factor produced by the endocrine cells of the islets of Langerhans is associated with a negative outcome of clinical islet transplantation. D iabetes 2005. 54(6):1755-1762.

99. Koh A, Senior P, Salam A, Kin T, Imes S, Dinyari P, Malcolm A, Toso C, Nilsson B, Korsgren O, et al. Insulin-heparin infusions peritransplant substantially improve single-donor clinical islet transplant success. T ransplantation 2010. 89(4):465-471.

100. Hirshberg B, Rother KI, Digon BJ 3rd, Lee J, Gaglia JL, Hines K, Read EJ, Chang R, Wood BJ, Harlan DM. Benefits and risks of solitary islet transplantation for type 1 diabetes using steroid-sparing immunosuppression: the $\mathrm{N}$ ational Institutes of $\mathrm{H}$ ealth experience. Diabetes $\mathrm{C}$ are 2003. 26(12):3288-3295.

101. Ryan EA, Paty BW, Senior PA, Shapiro AM. R isks and side effects of islet transplantation. Curr $D$ iabetes $R$ ep 2004. 4(4):304-309.

102. Kawahara T, Kin T, Kashkoush S, Gala-Lopez B, Bigam DL, Kneteman NM, Koh A, Senior PA, Shapiro AM. Portal vein thrombosis is a potentially preventable complication in clinical islet transplantation. A m J T ransplant 2011. 11(12):2700-2707.

103. Kawahara T, Kin T, Shapiro AM. A comparison of islet autotransplantation with allotransplantation and factors elevating acute portal pressure in clinical islet transplantation. J H epatobiliary Pancreat Sá 2012. 19(3):281-288.

104. R afael E, R yan EA, Paty BW, O berholzer J, Imes S, Senior P, MCDonald C, Lakey JR, Shapiro AM. Changes in liver enzymes after clinical islet transplantation. T ransplantation 2003. 76(9):1280-1284.

105. Bhargava R, Senior PA, Ackerman TE, Ryan EA, Paty BW, Lakey JR, Shapiro AM. Prevalence of hepatic steatosis after islet transplantation and its relation to graft function. D iabetes 2004. 53(5):1311-1317.

106. Maffi P, Angeli E, Bertuzzi F, Paties C, Socci C, Fedeli C, De Taddeo F, Nano R, Di Carlo V, Del Maschio A, et al. M inimal focal steatosis of liver after islet transplantation in humans: a long-term study. C ell T ransplant 2005. 14(10):727-733.

107. Markmann JF, Rosen M, Siegelman ES, Soulen MC, Deng S, Barker CF, Naji A. M agnetic resonance-defined periportal steatosis following intraportal islet transplantation: a functional footprint of islet graft survival? D iabetes 2003.
52(7):1591- 1594

108. Low G, Hussein N, O wen RJ, Toso C, Patel VH, Bhargava R, Shapiro AM. R ole of imaging in clinical islet transplantation. R adiographics 2010. 30(2):353-366.

109. T oso C, Isse K, Demetris AJ, Dinyari P, Koh A, Imes S, Kin T, Emamaullee J, Senior P, Shapiro AM. His tologic graft assessment after clinical islet transplantation. T ransplantation 2009. 88(11):1286-1293.

110. Dombrowski F, Bannasch P, Pfeifer U. Hepatocellular neoplasms induced by low-number pancreatic islet transplants in streptozotocin diabetic rats. A m J Pathol 1997. 150(3):1071-1087.

111. Dombrowski F, Mathieu C, Evert M. Hepatocellular neoplasms induced by low-number pancreatic islet transplants in autoimmune diabetic BB/ Pfd rats. C ancer R es 2006. 66(3):1833-1843.

112. Najarian JS, Sutherland DE, Matas AJ, Goetz FC. H uman islet autotransplantation following pancreatectomy. T ransplant P roc 1979. 11(1):336-340.

113. Najarian JS, Sutherland DE, Matas AJ, Steffes MW, Simmons RL, Goetz FC. H uman islet transplantation: a preliminary report. T ransplant P roc 1977. 9(1):233-236.

114. Sutherland DE, Matas AJ, Najarian JS. Pancreas and islet transplantation. W orld I Surg 1977. 2(1):185-195.

115. Humar A, Fishman JA. Donor-derived infection: old problem, new solutions? A m J T ransplant 2008. 8(6):10871088.

116. Len 0, Gavalda J, Blanes M, Montejo M, San Juan R, Moreno A, Carratala J, de la Torre-Cisneros J, Bou G, Cordero E, et al. Donor infection and transmission to the recipient of a solid allograft. A m J T ransplant 2008. 8(11):2420-2425.

117. Srinivasan A, Burton EC, Kuehnert MJ, Rupprecht C, Sutker WL, Ksiazek T G, Paddock CD, Guarner J, Shieh WJ, Goldsmith C, et al. Transmission of rabies virus from an organ donor to four transplant recipients. N E ngl J M ed 2005. 352(11):1103-1111.

118. Morris MI, Fischer SA, Ison MG. Infections transmitted by transplantation. Infed D is C lin N orth A m 2010. 24(2):497514.

119. Barshes NR, Agee EE, Zgabay T, Brunicardi FC, Goss JA, DeBakey ME. W est N ile Virus encephalopathy following pancreatic islet transplantation. A m J T ransplant 2006. 6(12):3037.

120. Humar A, Morris M, Blumberg E, Freeman R, Preiksaitis J, Kiberd B, Schweitzer E, Ganz S, Caliendo A, Orlowski JP, et al. Nucleic acid testing (NAT) of organ donors: is the 'best' test the right test? A consensus conference report. Am J Transplant 2010. 10(4):889-899.

121. Senior P, Kin T, Shapiro J, Koh A. I slet transplantation at the U niversity of Alberta: status update and review of progress over the last decade. C anad J D iabetes 2012. 36(1):32-37.

122. Alberu J, Pascoe MD, Campistol JM, Schena FP, Rial Mdel C, Polinsky M, Neylan JF, Korth-Bradley J, Goldberg-Alberts R, Maller ES. Lower malignancy rates in renal allograft recipients converted to sirolimus-based, calcineurin inhibitor-free immunotherapy: 24-month results from the CON VER T trial. T ransplantation 2011. 92(3):303310.

123. Kahan BD, Yakupoglu YK, Schoenberg L, Knight RJ, Katz SM, Lai D, Van Buren CT. Low incidence of 
malignancy among sirolimus/ cyclosporine-treated renal transplant recipients. T ransplantation 2005. 80(6):749-758.

124. Geisser EK, Schlitt HJ. The potential benefits of rapamycin on renal function, tolerance, fibrosis, and malignancy following transplantation. K idney Int 2010. 78(11):1075-1079.

125. Manuelli M, De Luca L, Iaria G, Tatangelo P, Sforza D, Perrone L, Bellini MI, Angelico R, Anselmo A, Tisone G. Conversion to rapamycin immunosuppression for malignancy after kidney transplantation. T ransplant P roc 2010. 42(4):1314-1316.

126. Feldmeyer L, Hofbauer GF, Boni T, French LE, H afner J. M ammalian target of rapamycin (mTOR ) inhibitors slow skin carcinogenesis, but impair wound healing. B rit I D ermatol 2012. 166(2):422-424.

127. Campbell SB, Walker $\mathbf{R}$, Tai SS, Jiang Q, R uss GR. $\mathrm{R}$ andomized controlled trial of sirolimus for renal transplant recipients at high risk for nonmelanoma skin cancer. A m J T ransplant 2012. 12(5):1146- 1156.

128. Geissler EK, Schlitt HJ. Transplantation: can sirolimus prevent skin cancer in transplant recipients? $\mathrm{N}$ at $\mathrm{R}$ ev $\mathrm{N}$ ephrol 2010. 6(11):639-641.

129. Decaens T, Luciani A, Itti E, Hulin A, RoudotThoraval F, Laurent A, Z afrani ES, Mallat A, Duvoux C. Phase II study of sirolimus in treatment-naive patients with advanced hepatocellular carcinoma. D ig L iver D is 2012. 44(7):610-616.

130. Liang W, Wang D, Ling X, Kao AA, Kong Y, Shang $\mathbf{Y}$, Guo $\mathbf{Z}$, He $\mathbf{X}$. Sirolimus-based immunosuppression in liver transplantation for hepatocellular carcinoma: a metaanalysis. L iver T ransplant 2012. 18(1):62-69.

131. T oso C, Merani S, Bigam DL, Shapiro AM, Kneteman NM. Sirolimus based immunosuppression is associated with increased survival after liver transplantation for hepatocellular carcinoma. H epatology 2010. 51(4):1237-1243.

132. Campbell PM, Senior PA, Salam A, Labranche K, Bigam DL, Kneteman NM, Imes S, Halpin A, Ryan EA, Shapiro AM. H igh risk of sensitization after failed islet transplantation. A m J T ransplant 2007. 7(10):2311-2317.

133. Ferrari-Lacraz S, Berney T, Morel P, Marangon N, Hadaya K, Demuylder-Mischler S, Pongratz G, Pernin N, Villard J. Low risk of anti-human leukocyte antigen antibody sensitization after combined kidney and islet transplantation. T ransplantation 2008. 86(2):357-359.

134. Moreau F, Toti F, Bayle F, Berney T, Egelhofer $\mathbf{H}$, Chastre M, Richard MJ, Greget M, Masson D, Zobairi $\mathbf{F}$, et al. $\mathrm{R}$ escue of a pancreatic islet graft after steroid therapy. T ransplantation 2012. 93(3):e10-11.

135. Kessler L, Parissiadis A, Bayle F, Moreau F, Pinget M, Froelich N, Cazenave JP, Berney $T$, Benhamou PY, H anau D, et al. Evidence for humoral rejection of a pancreatic islet graft and rescue with rituximab and IV immunoglobulin therapy. A m J Transplant 2009. 9(8):19611966.

136. Stiller CR, D upre J, Gent M, Jenner MR, Keown PA, Laupacis A, Martell R, Rodger NW, von Graffenried B, Wolfe BM. Effects of cyclosporine immunosuppression in insulin-dependent diabetes mellitus of recent onset. Sience 1984. 223(4643):1362-1367.

137. Sutherland DE, Sibley $R, X \mathbf{X} X Z$, Michael A, Srikanta AM, Taub F, Najarian J, Goetz FC. T win-totwin pancreas transplantation: reversal and reenactment of the pathogenesis of type I diabetes. T rans A ssoc A m Physidans 1984. 97:80-87.
138. Sutherland DE, Gruessner RW, Dunn DL, Matas AJ, Humar A, Kandaswamy R, Mauer SM, Kennedy WR, Goetz FC, Robertson RP, et al. Lessons learned from more than 1,000 pancreas transplants at a single institution. A nn Surg 2001. 233(4):463-501.

139. Burke GW 3rd, Vendrame F, Pileggi A, Ciancio G, Reijonen $\mathbf{H}$, Pugliese A. R ecurrence of autoimmunity following pancreas transplantation. C urr D iabetes R ep 2011. 11(5):413-419.

140. Worcester Human Islet Transplantation Group. Autoimmunity after islet-cell allotransplantation. N Engl J M ed 2006. 355(13):1397-1399.

141. Markees TG, Serreze DV, Phillips NE, Sorli CH, Gordon EJ, Shultz LD, Noelle RJ, Woda BA, Greiner DL, Mordes JP, et al. N OD mice have a generalized defect in their response to transplantation tolerance induction. D iabetes 1999. 48(5):967-974.

142. Shoda LK, Young DL, Ramanujan S, Whiting CC, Atkinson MA, Bluestone JA, Eisenbarth GS, Mathis D, Rossini AA, Campbell SE, et al. A comprehensive review of interventions in the NOD mouse and implications for translation. Immunity 2005. 23(2):115-126.

143. Hilbrands R, Huurman VA, Gillard P, Velthuis JH, De Waele M, Mathieu C, Kaufman L, PipeleersMarichal M, Ling Z, Movahedi B, et al. Differences in baseline lymphocyte counts and autoreactivity are associated with differences in outcome of islet cell transplantation in type 1 diabetic patients. D iabetes 2009. 58(10):2267-2276.

144. Chatenoud L. Chemical immunosuppression in islet transplantation - friend or foe? N Engl J M ed 2008. 358(11):11921193.

145. Desai NM, Goss JA, Deng S, Wolf BA, Markmann E, Palanjian M, Shock AP, Feliciano S, Brunicardi FC, Barker CF, et al. Elevated portal vein drug levels of sirolimus and tacrolimus in islet transplant recipients: local immunosuppression or islet toxicity? Transplantation 2003. 76(11):1623-1625.

146. Shapiro AM, Gallant HL, Hao EG, Lakey JR, McCready $T$, Rajotte RV, Y atscoff RW, Kneteman NM. The portal immunosuppressive storm: relevance to is let transplantation? T her D rug M onit 2005. 27(1):35-37.

147. Nir T, Melton DA, Dor Y. R ecovery from diabetes in mice by beta cell regeneration. I C lin Invest 2007. 117(9):2553-2561.

148. Bellin MD, Barton FB, Heitman A, Harmon JV, Kandaswamy $R$, Balamurugan AN, Sutherland DE, Alejandro R, Hering BJ. Potent induction immunotherapy promotes long-term insulin independence after islet transplantation in type 1 diabetes. A m J T ransplant 2012. 12(6):1576-1583.

149. Barton FB, Rickels MR, Alejandro R, Hering BJ, Wease S, Naziruddin B, O berholzer J, O dorico JS, Garfinkel MR, Levy $\mathbf{M}$, et al. Improvement in outcomes of clinical islet transplantation: 1999-2010. D iabetes C are 2012. 35(7):1436-1445.

150. Gottlieb PA, Quinlan S, Krause-Steinrauf H, Greenbaum CJ, Wilson DM, Rodriguez H, Schatz DA, Moran AM, Lachin JM, Skyler JS. Failure to preserve beta-cell function with mycophenolate mofetil and daclizumab combined therapy in patients with new-onset type 1 diabetes. D iabetes $C$ are 2010. 33(4):826-832.

151. Bellin MD, Barton FB, Heitman A, Harmon J, Bala murugan AN, Kandaswamy $R$, Sutherland DE, Ale- 
jandro R, Hering BJ. Potent induction immunotherapy promotes long-term insulin independence after islet trans plantation in type 1 diabetes. A m J Transplant 2012. 12(6):1576-1583.

152. Bellin MD, Kandaswamy R, Parkey J, Zhang HJ, Liu B, Ihm SH, Ansite JD, Witson J, Bansal-Pakala P, Balamurugan AN, et al. Prolonged insulin independence after islet allotransplants in recipients with type 1 diabetes. A m J T ransplant 2008. 8(11):2463-2470.

153. Hering BJ. Achieving and maintaining insulin independence in human islet transplant recipients. T ransplantation 2005. 79(10):1296-1297.

154. Parker MJ, Xue S, Alexander J, Wasserfall CH, Campbell-Thompson ML, Battaglia M, Gregori S, Mathews $\mathbf{C E}$, Song $\mathbf{S}$, $\mathbf{T}$ routt $\mathbf{M}$, et al. Immune depletion with cellular mobilization imparts immunoregulation and reverses autoimmune diabetes in nonobese diabetic mice. D iabetes 2009. 58(10):2277-2284.

155. Ildstad ST, Chilton PM, X u H, Domenick MA, Ray MB. Preconditioning of NOD mice with anti-CD $8 \mathrm{mAb}$ and costimulatory blockade enhances chimerism and tolerance and prevents diabetes, while depletion of alpha betaTCR + and CD4+ cells negates the effect. Blood 2005. 105(6):2577-2584.

156. G landt $\mathbf{M}$, Herold $\mathbf{K C}$. T reatment of type 1 diabetes with anti- $T$-cell agents: from $T$-cell depletion to $T$-cell regulation. C urr D iabetes R ep 2004. 4(4):291-297.

157. R oep BO, Peakman M. Antigen targets of type 1 diabetes autoimmunity. Cold Spring Harb Perspect M ed 2012. 2(4): 2007781.

158. R oep BO, Buckner J, Sawcer S, Toes R, Z ipp F. The problems and promises of research into human immunology and autoimmune disease. $N$ at M ed 2012. 18(1):48-53.

159. Clatworthy MR, Friend PJ, Calne RY, Rebello PR, Hale G, Waldmann H, Watson CJ. Alemtuzumab (CAMPATH-1H) for the treatment of acute rejection in kidney transplant recipients: long-term follow-up. T ransplantation 2009. 87(7):1092-1095.

160. Watson CJ, Bradley JA, Friend PJ, Firth J, T aylor CJ, Bradley JR, Smith KG, Thiru S, Jamieson NV, Hale G, et al. Alemtuzumab (CAM PATH $1 \mathrm{H}$ ) induction therapy in cadaveric kidney transplantation - efficacy and safety at five years. A m J T ransplant 2005. 5(6):1347-1353.

161. Calne R, Friend P, Moffatt S, Bradley A, Hale G, Firth J, Bradley J, Smith K, Waldmann H. Prope tolerance, perioperative campath $1 \mathrm{H}$, and low-dose cyclosporin monotherapy in renal allograft recipients. Lancet 1998. 351(9117):1701-1702.

162. Newell KA, Cendales LC, Kirk AD. Finding the right job for the tool: alemtuzumab and its role in renal transplantation. A m J T ransplant 2008. 8(7):1363-1364.

163. Kirk AD, Hale DA, Mannon RB, Kleiner DE, Hoffmann SC, Kampen RL, Cendales LK, Tadaki DK, Harlan DM, Swanson SJ. R esults from a human renal allograft tolerance trial evaluating the humanized CD52specific monoclonal antibody alemtuzumab (CAMPATH 1H). T ransplantation 2003. 76(1):120-129.

164. Knechtle SJ, Pirsch JD, H. Fechner J J, Becker BN, Friedl A, Colvin RB, Lebeck LK, Chin LT, Becker YT, O dorico JS, et al. Campath- $1 \mathrm{H}$ induction plus rapamycin monotherapy for renal transplantation: results of a pilot study. A m J T ransplant 2003. 3(6):722-730.

165. Knechtle SJ, Fernandez LA, Pirsch JD, Becker BN,
Chin LT, Becker YT, O dorico JS, D'Alessandro AM, Sollinger HW. Campath- $1 \mathrm{H}$ in renal transplantation: The U niversity of W isconsin experience. Surgery 2004. 136(4):754-760

166. Gala-Lopez BL, Senior PA, Koh A, Kashkoush SM, Kawahara T, Kin T, Humar A, Shapiro AM. Late cytomegalovirus transmission and impact of $\mathrm{T}$-depletion in clinical islet transplantation. A m J Transplant 2011. 11(12):2708-2714.

167. Toso C, Edgar R, Pawlick R, Emamaullee J, Merani $S$, Dinyari $P$, Mueller TF, Shapiro AM, Anderson CC. Effect of different induction strategies on effector, regulatory and memory lymphocyte sub-populations in clinical islet transplantation. T ransplant Int 2009. 22(2):182191.

168. Hafiz MM, Poggioli R, Caulfield A, Messinger S, Geiger MC, Baidal DA, Froud T, Ferreira JV, Tzakis AG, Ricordi C, et al. Cytomegalovirus prevalence and transmission after islet allograft transplant in patients with type 1 diabetes mellitus. A m J T ransplant 2004. 4(10):16971702.

169. Farney AC, Xenos E, Sutherland DE, Widmer M, Stephanian E, Field MJ, Kaufman DB, Stevens RB, Blazar B, Platt J, et al. Inhibition of pancreatic islet beta cell function by tumor necrosis factor is blocked by a soluble tumor necrosis factor receptor. T ransplant Proc 1993. 25(1 Pt 2):865-866.

170. McCall M, Pawlick R, Kin T, Shapiro AM. Anakinra potentiates the protective effects of etanercept in transplantation of marginal mass human islets in immunodeficient mice. A m J T ransplant 2012. 12(2):322-329.

171. Matsumoto S, Takita M, Chaussabel D, Noguchi H, Shimoda M, Sugimoto K, Itoh T, Chujo D, Sorelle J, O naca $\mathbf{N}$, et al. Improving efficacy of clinical islet transplantation with Iodixanol based islet purification, thymoglobulin induction and blockage of IL-1-beta and TNFalpha. C ell T ransplant 2011. 20(10):1641-1647.

172. Moberg L, Johansson H, Lukinius A, Berne C, Foss A, Kallen R, Ostraat 0 , Salmela $K$, Tibell A, Tufveson $\mathbf{G}$, et al. Production of tissue factor by pancreatic islet cells as a trigger of detrimental thrombotic reactions in clinical islet transplantation. $L$ ancet 2002. 360(9350):2039- 2045.

173. Nilsson B, Ekdahl KN, Korsgren O. Control of instant blood-mediated inflammatory reaction to improve islets of Langerhans engraftment. C urr 0 pin 0 rgan T ransplant 2011. 16(6):620-626.

174. Eriksson O, Eich T, Sundin A, Tibell A, Tufveson G, Andersson H, Felldin M, Foss A, Kyllonen L, Langstrom B, et al. Positron emission tomography in clinical islet transplantation. A m J T ransplant 2009. 9(12):2816-2824.

175. Eich T, Eriksson O, Lundgren T. Visualization of early engraftment in clinical islet transplantation by positronemission tomography. N Engl J Med 2007. 356(26):27542755.

176. Cabric S, Sanchez J, Lundgren T, Foss A, Felldin M, Kallen R, Salmela K, Tibell A, Tufveson G, Larsson $\mathbf{R}$, et al. Islet surface heparinization prevents the instant blood-mediated inflammatory reaction in islet transplantation. D iabetes 2007. 56(8):2008-2015.

177. Emamaullee JA, Shapiro AM. Interventional strategies to prevent beta-cell apoptosis in islet transplantation. D iabetes 2006. 55(7):1907-1914.

178. Emamaullee JA, Rajotte RV, Liston P, Korneluk RG, 
Lakey JR, Shapiro AM, Elliott JF. XIAP overexpression in human islets prevents early posttransplant apoptosis and reduces the islet mass needed to treat diabetes. D iabetes 2005. 54(9):2541-2548.

179. Emamaullee J, Liston P, Korneluk RG, Shapiro AM, Elliott JF. X IAP overexpression in islet beta-cells enhances engraftment and minimizes hypoxia- reperfusion injury. A $\mathrm{m}$ J T ransplant 2005. 5(6):1297-1305.

180. Emamaullee JA, Stanton L, Schur C, Shapiro AM. C aspase inhibitor therapy enhances marginal mass islet graft survival and preserves long-term function in islet transplantation. D iabetes 2007. 56(5):1289-1298.

181. Emamaullee JA, Davis J, Pawlick R, T oso C, Merani S, Cai SX, T seng B, Shapiro AM. The caspase selective inhibitor EP1013 augments human islet graft function and longevity in marginal mass islet transplantation in mice. D iabetes 2008. 57(6):1556-1566.

182. Emamaullee JA, Davis J, Pawlick R, T oso C, Merani S, Cai SX, Tseng B, Shapiro AM. Caspase inhibitor therapy synergizes with costimulation blockade to promote indefinite islet allograft survival. D iabetes 2010. 59(6):14691477.

183. McCall M, Toso C, Emamaullee J, Pawlick R, Edgar R, Davis J, Maciver A, Kin T, Arch R, Shapiro AM. The caspase inhibitor IDN-6556 (PF3491390) improves marginal mass engraftment after islet transplantation in mice. Surgery 2011. 150(1):48- 55 .

184. Faradji RN, Froud T, Messinger S, Monroy K, Pileggi A, Mineo D, Tharavanij T, Mendez AJ, Ricordi C, Alejandro R. Long-term metabolic and hormonal effects of exenatide on islet transplant recipients with allograft dysfunction. C ell T ransplant 2009. 18(10):1247-1259.

185. Froud T, Ricordi C, Alejandro R. Exenatide U se in Islet Transplantation - R easons to $R$ emain Optimistic. T ransplantation 2009. 87(1):154.

186. Rickels MR, Naji A. Exenatide use in islet transplantation: words of caution. T ransplantation 2009. 87(1):153.

187. Faradji RN, Tharavanij T, Messinger S, Froud T, Pileggi A, Monroy K, Mineo D, Baidal DA, Cure P, Ponte G, et al. Long-term insulin independence and improvement in insulin secretion after supplemental islet infusion under exenatide and etanercept. T ransplantation 2008. 86(12):1658-1665.

188. Froud T, Faradji RN, Pileggi A, Messinger S, Baidal DA, Ponte GM, Cure PE, Monroy $K$, Mendez A, Selvaggi G, et al. The use of exenatide in islet transplant recipients with chronic allograft dysfunction: safety, efficacy, and metabolic effects. T ransplantation 2008. 86(1):36-45.

189. Ghofaili KA, Fung M, Ao Z, Meloche M, Shapiro RJ, Warnock GL, Elahi D, Meneilly GS, Thompson DM. Effect of exenatide on beta cell function after islet transplantation in type 1 diabetes. T ransplantation 2007. 83(1):24-28.

190. Gangemi A, Salehi P, Hatipoglu B, Martellotto J, Barbaro B, Kuechle JB, Qi M, Wang Y, Pallan P, O wens C, et al. I slet transplantation for brittle type 1 diabetes: the UIC protocol. A m J Transplant 2008. 8(6):12501261.

191. Merani S, Truong W, Emamaullee JA, Toso C, Knudsen LB, Shapiro AM. Liraglutide, a long-acting human glucagon-like peptide 1 analog, improves glucose homeostasis in marginal mass islet transplantation in mice. E ndocinology 2008. 149(9):4322-4328

192. Emamaullee JA, Merani S, T oso C, Kin T, Al-Saif F,
Truong W, Pawlick R, Davis J, Edgar R, Lock J, et al. Porcine marginal mass islet autografts resist metabolic failure over time and are enhanced by early treatment with liraglutide. Endocinology 2009. 150(5):2145-2152.

193. T oso C, McCall M, Emamaullee J, Merani S, Davis J, Edgar R, Pawlick R, Kin T, Knudsen LB, Shapiro AM. Liraglutide, a long-acting human glucagon-like peptide 1 analogue, improves human islet survival in culture. T ransplant Int 2010. 23(3):259-265.

194. Berney T. Liraglutide in islet transplantation: from bench to bedside. T ransplant Int 2010. 23(3):257-258.

195. Ojo AO, Held PJ, Port FK, Wolfe RA, Leichtman $A B$, Young EW, Arndorfer J, Christensen L, Merion R M. C hronic renal failure after transplantation of a nonrenal organ. N Engl J M ed 2003. 349(10):931-940.

196. Leitao CB, Cure P, Messinger S, Pileggi A, Lenz O, Froud T, Faradji RN, Selvaggi G, Kupin W, Ricordi C, et al. Stable renal function after islet transplantation: importance of patient selection and aggressive clinical management. T ransplantation 2009. 87(5):681-688.

197. Shapiro AM, Lakey JR, Paty BW, Senior PA, Bigam DL, Ryan EA. Strategic opportunities in clinical islet transplantation. T ransplantation 2005. 79(10):1304-1307.

198. Shapiro AM, Ricordi C, Hering BJ, Auchincloss H, Lindblad R, R obertson RP, Secchi A, Brendel MD, Berney T, Brennan DC, et al. International trial of the Edmonton protocol for islet transplantation. N E ngl J M ed 2006. 355(13):1318-1330.

199. Shapiro AM, Ricordi C, Hering B. Edmonton's islet success has indeed been replicated elsewhere. Lancet 2003. 362(9391): 1242.

200. Berney T, Secchi A. R apamycin in islet transplantation: friend or foe? T ransplant Int 2009. 22(2):153-161.

201. Alfadhli E, Koh A, Albaker W, Bhargava R, Ackerman T, McDonald C, Ryan EA, Shapiro AM, Senior PA. High prevalence of ovarian cysts in premenopausal women receiving sirolimus and tacrolimus after clinical islet transplantation. T ransplant Int 2009. 22(6):622-625.

202. Del OImo Garcia MI, Lauriola V, Gomez Aracena A, Messinger S, Corrales A, Ricordi C, Alejandro R. Alterations of the female reproductive system in islet recipient receiving immunosuppression. Cell Transplant 2011. 20(10):1649-1651.

203. Cure $\mathbf{P}$, Pileggi A, Froud T, Norris PM, Baidal DA, Cornejo A, Hafiz MM, Ponte G, Poggioli R, Yu J, et al. Alterations of the female reproductive system in recipients of islet grafts. T ransplantation 2004. 78(11):1576- 1581.

204. Molinari M, Al-Saif F, Ryan EA, Lakey JR, Senior PA, Paty BW, Bigam DL, Kneteman NM, Shapiro AM. Sirolimus-induced ulceration of the small bowel in islet transplant recipients: report of two cases. A m J T ransplant 2005. 5(11):2799-2804.

205. Digon BJ 3rd, Rother KI, Hirshberg B, Harlan DM. Sirolimus-induced interstitial pneumonitis in an islet transplant recipient. D iabetes C are 2003. 26(11):3191.

206. Senior PA, Shapiro AM, Ackerman TE, Ryan EA, Paty BW, Bhargava R. M agnetic resonance-defined perinephric edema after clinical islet transplantation: a benign finding associated with mild renal impairment. T ransplantation 2004. 78(6): 945-948.

207. Leitao CB, Froud T, Cure P, Tharavanij T, Pileggi A, Ricordi C, Alejandro R. N onalbumin proteinuria in islet transplant recipients. C ell Transplant 2010. 19(1):119- 
125.

208. Senior PA, Paty BW, Cockfield SM, Ryan EA, Shapiro AM. Proteinuria developing after clinical islet transplantation resolves with sirolimus withdrawal and increased tacrolimus dosing. A m J T ransplant 2005. 5(9):23182323.

209. Turgeon NA, Avila JG, Cano JA, Hutchinson JJ, Badell IR, Page AJ, Adams AB, Sears MH, Bowen PH, Kirk AD, et al. Experience with a novel efalizumabbased immunosuppressive regimen to facilitate single donor islet cell transplantation. A m J T ransplant 2010. 10(9):20822091.

210. Kothary N, Diak IL, Brinker A, Bezabeh S, Avigan M, Dal Pan G. Progressive multifocal leukoencephalopathy associated with efalizumab use in psoriasis patients. I A m A cad D ermatol 2011. 65(3):546-551.

211. Gadzia J, T urner J. Progressive multifocal leukoencephalopathy in two psoriasis patients treated with efalizumab. J D rug D ermatol 2010. 9(8):1005-1009.

212. Carson KR, Focosi D, Major EO, Petrini M, Richey EA, West DP, Bennett CL. Monoclonal antibodyassociated progressive multifocal leucoencephalopathy in pa tients treated with rituximab, natalizumab, and efalizumab: a review from the R esearch on Adverse Drug Events and $R$ eports (R AD AR ) Project. Lancet 0 ncol 2009. 10(8):816-824.

213. Ryan EA, Paty BW, Senior PA, Bigam D, Alfadhli E, Kneteman NM, Lakey JR, Shapiro AM. Five-year follow-up after clinical islet transplantation. D iabetes 2005 54(7):2060-2069.

214. T iwari JL, Schneider B, Barton F, Anderson SA. Islet cell transplantation in type 1 diabetes: an analysis of efficacy outcomes and considerations for trial designs. A m J T ransplant 2012. 12(7):1898-907.

215. Berney T, Ferrari-Lacraz S, Buhler L, Oberholzer J, Marangon N, Philippe J, Villard J, Morel P. Long-term insulin-independence after allogeneic islet transplantation for type 1 diabetes: over the 10-year mark. A m J T ransplant 2009. 9(2):419-423.

216. Gibly RF, Graham JG, Luo X, Lowe WL Jr, Hering BJ, Shea LD. Advancing islet transplantation: from engraftment to the immune response. Diabetologia 2011. 54(10):2494-2505

217. Gruessner AC. 2011 update on pancreas transplantation: comprehensive trend analysis of 25,000 cases followed up over the course of twenty-four years at the International Pancreas T ransplant R egistry (IPT R ). R ev D iabet Stud 2011. $8(1): 6-16$.

218. Payne WD, Sutherland DE, Matas AJ, Najarian JS. A melioration of diabetes in rats by transplantation of islet tissue from a single donor to multiple recipients. Surg Forum 1977. 28:301-304.

219. Griffin SM, Alderson D, Farndon JR. Comparison of harvesting methods for islet transplantation. B rit J Surg 1986. 73(9):712-715.

220. Matsumoto S, Okitsu T, Iwanaga Y, Noguchi H, Nagata H, Y onekawa Y, Y amada Y, Fukuda K, T sukiyama K, Suzuki $\mathbf{H}$, et al. Insulin independence after living-donor distal pancreatectomy and islet allotransplantation. Lancet 2005. 365(9471):1642-1644.

221. Shapiro AM, Ricordi C. U nraveling the secrets of single donor success in islet transplantation. A m J T ransplant 2004. 4(3):295-298.

222. H ypoglycemia in the Diabetes Control and Complications
Trial. The Diabetes Control and Complications Trial R esearch G roup. D iabetes 1997. 46(2):271-286.

223. The effect of intensive treatment of diabetes on the development and progression of long-term complications in insulin-dependent diabetes mellitus. T he Diabetes Control and Complications Trial R esearch Group. N Engl J M ed 1993. 329(14):977-986.

224. Gremizzi C, Vergani A, Paloschi V, Secchi A. Impact of pancreas transplantation on type 1 diabetes-related complications. C urr 0 pin 0 rgan T ransplant 2010. 15(1):119-123.

225. Lee TC, Barshes NR, Agee EE, O'Mahoney CA, Brunicardi FC, Goss JA. The effect of whole organ pancreas transplantation and PIT on diabetic complications. $C$ urr D iabetes $R$ ep 2006. 6(4):323-327.

226. Luzi L. Pancreas transplantation and diabetic complications. N Engl J M ed 1998. 339(2):115-117.

227. Becker BN, Brazy PC, Becker YT, Odorico JS, Pintar TJ, Collins BH, Pirsch JD, Leverson GE, Heisey DM, Sollinger HW. Simultaneous pancreas kidney transplantation reduces excess mortality in type 1 diabetic patients with end-stage renal disease. K idney Int 2000. 57(5):21292135.

228. Smets YF, Westendorp RG, van der Pijl JW, de Charro FT, Ringers J, de Fijter JW, Lemkes HH. Effect of simultaneous pancreas-kidney transplantation on mortality of patients with type- 1 diabetes mellitus and endstage renal failure. L ancet 1999. 353(9168):1915-1919.

229. Tyden G, Bolinder J, Solders G, Brattstrom C, Tibell A, Groth CG. Improved survival in patients with insulindependent diabetes mellitus and end-stage diabetic nephropathy 10 years after combined pancreas and kidney transplantation. T ransplantation 1999. 67(5):645-648.

230. Giannarelli R, Coppelli A, Sartini MS, Del Chiaro M, Vistoli F, Rizzo G, Barsotti M, Del Prato S, Mosca $\mathbf{F}$, Boggi $\mathbf{U}$, et al. Pancreas transplant alone has beneficial effects on retinopathy in type 1 diabetic patients. D iabetologia 2006. 49(12):2977-2982.

231. Koznarova R, Saudek F, Sosna T, Adamec M, Jedinakova T, Boucek P, Bartos V, Lanska V. Beneficial effect of pancreas and kidney transplantation on advanced diabetic retinopathy. C ell T ransplant 2000. 9(6):903-908.

232. Fioretto P, Mauer M. R eversal of diabetic nephropathy: lessons from pancreas transplantation. J N ephrol 2012. 25(1):13-18.

233. Fioretto P, Steffes MW, Sutherland DE, Goetz FC, Mauer M. R eversal of lesions of diabetic nephropathy after pancreas transplantation. N E ngl J M ed 1998. 339(2):69-75.

234. Kendall DM, Rooney DP, Smets YF, Salazar Bolding L, Robertson RP. Pancreas transplantation restores epinephrine response and symptom recognition during hypoglycemia in patients with long-standing type I diabetes and autonomic neuropathy. D iabetes 1997. 46(2):249-257.

235. Larsen JL, Ratanasuwan $\mathbf{T}$, Burkman $\mathbf{T}$, Lynch $\mathbf{T}$, Erickson J, Colling C, Lane J, Mack-Shipman L, Lyden $\mathbf{E}$, Loseke $\mathbf{M}$, et al. Carotid intima media thickness decreases after pancreas transplantation. T ransplantation 2002. 73(6):936-940.

236. Ojo AO, Meier-Kriesche HU, Hanson JA, Leichtman A, Magee JC, Cibrik D, Wolfe RA, Port FK, Agodoa L, Kaufman DB, et al. The impact of simultaneous pancreas-kidney transplantation on long-term patient survival. T ransplantation 2001. 71(1):82-90.

237. Fiorina P, Shapiro AM, Ricordi C, Secchi A. The 
clinical impact of islet transplantation. A m J T ransplant 2008 8(10):1990-1997.

238. Del Carro U, Fiorina P, Amadio S, De Toni Franceschini L, Petrelli A, Menini S, Martinelli Boneschi F, Ferrari S, Pugliese G, Maffi P, et al. Evaluation of polyneuropathy markers in type 1 diabetic kidney trans plant patients and effects of islet transplantation: neurophysiological and skin biopsy longitudinal analysis. D iabetes $C$ are 2007. 30(12):3063-3069.

239. Venturini $\mathbf{M}$, Fiorina $\mathbf{P}$, Maffi $\mathbf{P}$, Losio $\mathbf{C}$, Vergani $\mathbf{A}$, Secchi A, Del Maschio A. Early increase of retinal arterial and venous blood flow velocities at color Doppler imaging in brittle type 1 diabetes after islet transplant alone. T ransplantation 2006. 81(9):1274-1277.

240. Fiorina P, Gremizzi C, Maffi P, Caldara R, Tavano D, Monti L, Socci C, Folli F, Fazio F, Astorri E, et al. Islet transplantation is associated with an improvement of cardiovascular function in type 1 diabetic kidney transplant patients. D iabetes $C$ are 2005. 28(6):1358-1365.

241. Fiorina P, Folli F, Zerbini G, Maffi P, Gremizzi C, Di Carlo V, Socci C, Bertuzzi F, Kashgarian M, Secchi A. I slet transplantation is associated with improvement of renal function among uremic patients with type I diabetes mellitus and kidney transplants. J A m Soc N ephrol 2003. 14(8):2150-2158.

242. Fiorina $\mathbf{P}$, Folli $\mathbf{F}$, Maffi $\mathbf{P}$, Placidi C, Venturini $\mathbf{M}$, Finzi G, Bertuzzi F, Davalli A, D'Angelo A, Socci C, et al. Islet transplantation improves vascular diabetic complications in patients with diabetes who underwent kidney transplantation: a comparison between kidney-pancreas and kidney-alone transplantation. Transplantation 2003. 75(8):1296-1301.

243. Fiorina P, Folli F, Bertuzzi F, Maffi P, Finzi G, Venturini $M$, Socci $C$, Davalli A, Orsenigo $E$, Monti $L$, et al. Long-term beneficial effect of islet transplantation on diabetic macro-/ microangiopathy in type 1 diabetic kidneytransplanted patients. D iabetes $C$ are 2003. 26(4):1129-1136.

244. Thompson DM, Meloche M, Ao Z, Paty B, Keown P, Shapiro RJ, Ho S, Worsley D, Fung M, Meneilly $\mathbf{G}$, et al. R educed progression of diabetic microvascular complications with islet cell transplantation compared with intensive medical therapy. Transplantation 2011. 91(3):373378.

245. Warnock GL, Thompson DM, Meloche RM, Shapiro RJ, Ao Z, Keown P, Johnson JD, Verchere CB, Partovi N, Begg IS, et al. A multi-year analysis of islet transplantation compared with intensive medical therapy on progression of complications in type 1 diabetes. T ransplantation 2008. 86(12):1762-1766.
246. Danielson KK, Hatipoglu B, Kinzer K, Kaplan B, Martellotto J, Q i M, Mele A, Benedetti E, O berholzer J. R eduction in carotid intima-media thickness after pancreatic islet transplantation in patients with type 1 diabetes. $D$ iabetes $C$ are 2012. In press.

247. McCall MD, Toso C, Baetge EE, Shapiro AM. Are stem cells a cure for diabetes? C lin Sá 2010. 118(2):87-97.

248. Herold KC, Bluestone JA. Type 1 diabetes immunotherapy: is the glass half empty or half full? Sdi T ransl M ed 2011. 3(95):95fsl.

249. Voltarelli JC, Couri CE. Stem cell transplantation for type 1 diabetes mellitus. D iabetol M etabol Syndr 2009. 1(1):4.

250. Fiorina P, Voltarelli J, Z avazava N. Immunological applications of stem cells in type 1 diabetes. E ndocr R ev 2011. 32(6):725-754.

251. De Santis GC, de Pina Almeida Prado B Jr, de Lima Prata K, Brunetta DM, Orellana MD, Palma PV, Oliveira MC, Simoes BP, Voltarelli JC, Covas DT. Mobilization and harvesting of PBPC in newly diagnosed type 1 diabetes mellitus. Bone M arrow T ransplant 2012. 47(7):993-994.

252. Vantyghem MC, Raverdy V, Balavoine AS, Defrance F, Caiazzo R, Arnalsteen L, Gmyr V, Hazzan M, Noel C, Kerr-Conte J, et al. Continuous glucose monitoring after islet transplantation in type 1 diabetes: an excellent graft function (beta-score greater than 7 ) Is required to abrogate hyperglycemia, whereas a minimal function is necessary to suppress severe hypoglycemia (beta-score greater than 3). J C lin Endocinol M etab 2012. 97(11):E2078-E2083.

253. Berney T, Korsgren O, Posselt A, Pileggi A. Islet transplantation and beta-cell replacement therapies for diabetes. J T ransplant 2011. 2011:157840.

254. Markmann JF, Deng S, Huang $X$, Desai NM, Velidedeoglu EH, Lui C, Frank A, Markmann E, Palanjian M, Brayman K, et al. Insulin independence following isolated islet transplantation and single islet infusions. A nn Surg 2003. 237(6):741-749.

255. Posselt AM, Bellin MD, Tavakol M, Szot GL, Frassetto LA, Masharani U, Kerlan RK, Fong L, Vincenti FG, Hering BJ, et al. I slet transplantation in type 1 diabetics using an immunosuppressive protocol based on the antiLFA-1 antibody efalizumab. Am J Transplant 2010. 10(8):1870-1880.

256. Matsumoto S, Takita M, Chaussabel D, Noguchi $\mathbf{H}$, Shimoda M, Sugimoto K, Itoh T, Chujo D, Sorelle J, O naca $\mathbf{N}$, et al. Improving Efficacy of C linical Islet T ransplantation W ith Iodixanol-Based Islet Purification, Thymoglobulin Induction, and Blockage of IL-1beta and TNFalpha. C ell T ransplant 2011. 20(10):1641-1647. 